\title{
Mediterranean Journal of Hematology and Infectious Diseases
}

\section{$\underline{\text { Review Article }}$}

\section{Gene Therapy for Hemophilia: Facts and Quandaries in the $21^{\text {st }}$ Century}

Valder R. Arruda ${ }^{1,2,3}$ and Bhavya S. Doshi ${ }^{1,2}$.

${ }^{1}$ Divsion of Hematology, Children's Hospital of Philadelphia, Philadelphia PA USA.

${ }^{2}$ Department of Pediatrics, Perelman School of Medicine, University of Pennsylvania, Philadelphia PA USA.

${ }^{3}$ Raymond G. Perelman Center for Cellular and Molecular Therapeutics, Children's Hospital of Philadelphia, Philadelphia PA USA.

Competing interests: The authors declare no conflict of Interest.

Abstract. Therapy for hemophilia has evolved in the last 40 years from plasma-based concentrates to recombinant proteins and, more recently, to non-factor therapeutics. Along this same timeline, research in adeno-associated viral (AAV) based gene therapy vectors has provided the framework for early phase clinical trials initially for hemophilia B (HB) and now for hemophilia A. Successive lessons learned from early HB trials have paved the way for current advanced phase trials. Nevertheless, questions linger regarding 1) the optimal balance of vector dose to transgene expression, 2) amount and durability of transgene expression required, and 3) long-term safety. Some trials have demonstrated unique findings not seen previously regarding transient elevation of liver enzymes, immunogenicity of the vector capsid, and loss of transgene expression. This review will provide an update on the clinical AAV gene therapy trials in hemophilia and address the questions above. A thoughtful and rationally approached expansion of gene therapy to the clinics would certainly be a welcome addition to the arsenal of options for hemophilia therapy. Further, the global impact of gene therapy could be vastly improved by expanding eligibility to different patient populations and to developing nations. With the advances made to date, it is possible to envision a shift from the early goal of simply increasing life expectancy to a significant improvement in quality of life by reduction in spontaneous bleeding episodes and disease complications.

Keywords: Adeno-associated virus; Gene therapy; Hemophilia.

Citation: Arruda V.R., Doshi B.S. Gene therapy for hemophilia: facts and quandaries in the $21^{\text {st }}$ century. Mediterr J Hematol Infect Dis 2020 , 12(1): e2020069, DOI: http://dx.doi.org/10.4084/MJHID.2020.069

This is an Open Access article distributed under the terms of the Creative Commons Attribution License (https://creativecommons.org/licenses/by-nc/4.0), which permits unrestricted use, distribution, and reproduction in any medium, provided the original work is properly cited.

Correspondence to: Valder R. Arruda, MD, PhD. Children's Hospital of Philadelphia, 3501 Civic Center Blvd, 5056 Colket Translational Research Center, Philadelphia, PA 19104. Tel.: (215) 590-4907, Fax: (215) 590-3660. E-mail: arruda@email.chop.edu

Bhavya S. Doshi, MD. Children's Hospital of Philadelphia, 3501 Civic Center Blvd, 5024 Colket Translational Research Center, Philadelphia, PA 19104. Tel.: (215) 590-3437, Fax: (215) 590-3992. E-mail: doshibs@email.chop.edu

Introduction. Hemophilia is a bleeding disorder that results from mutations in the $F 8$ or $F 9$ genes encoding coagulation factors VIII (FVIII) or IX (FIX), respectively. Deficiency or dysfunction of these clotting factors disrupts the coagulation system and results in frequent, spontaneous bleeding into the joints leading to chronic arthropathy, the hallmark of severe disease ( $<1 \%$ normal FVIII or FIX activity). In severe disease, people with hemophilia $(\mathrm{PwH})$ are infused intravenously with recombinant or plasma-derived factor concentrates for prophylaxis against joint bleeds. ${ }^{1}$ In patients with FVIII deficiency or hemophilia A (HA), 
replacement therapy with standard half-life products is required 2-3 times per week, whereas therapy with standard half-life FIX in hemophilia B (HB) is required twice per week. The advent of extended half-life (EHL) products ${ }^{2,3}$ has dramatically changed the infusion burden for HB patients to as infrequently as once every 2 weeks, whereas currently licensed EHL FVIII products have not had as dramatic of an increased half-life (up to 1.5-fold) presumably due to the limitations imposed by von Willebrand factor (VWF), the carrier for FVIII in circulation. ${ }^{4}$ Recent advances with non-factor therapies (NFTs) that either mimic the cofactor function of activated FVIII (emicizumab) (5,6 $^{5,6}$ or aim to "rebalance" the coagulation system by decreasing natural anticoagulants (antithrombin, ${ }^{7}$ tissue factor pathway inhibitor, ${ }^{8}$ and protein $\mathrm{C}^{9,10}$ ) are revolutionizing the need for intravenous factor therapy for prophylaxis but at this time cannot be used to treat bleeding episodes (see the chapter by Dr. Makris and Dr. Castaman) and have been associated with thrombotic complications in some patients. ${ }^{11,12}$

Robust preclinical development of a liver-directed gene-based therapeutic approach for hemophilia has culminated in promising clinical trial data by several independent groups (Figure 1). These trials support the prospect of a one-time infusion that could modify the hemophilia phenotype, thus offering several potential advantages compared to the current system of therapies. Hemophilia served as a model disease for gene therapy trials due to its monogenic nature, straightforward assessment of the efficacy by measurement of circulating FVIII or FIX levels, and easily quantifiable clinical endpoints such as bleeding rates and consumption of clotting factor concentrates. Further supporting its appeal is the ability to improve outcomes with even the modest efficacy of raising factor levels to $>1 \%$ (the goal of prophylactic factor replacement). Firstin-human gene therapy trials for hemophilia using retroviral or adenoviral vector for liver gene therapy, or non-viral vector-based approaches for skin fibroblast transduction and implantation into the omentum were hampered by limited and transient efficacy and immune responses to some viral vectors. ${ }^{13}$ Moreover, the use of integrating murine retroviral vector to genetically modified hematopoietic stem and progenitor cells (HSPC) for some primary immunodeficiencies raised concerns for oncogenicity. ${ }^{14}$ The hemophilia clinical studies in progress are based on the use of recombinant adeno-associated viral (rAAV) vectors, which have demonstrated efficacy and safety. In some AAV-based strategies, long-term improvement of the disease phenotype with an excellent safety profile was achieved; these data will be discussed below. Strategies using rAAV vectors targeting skeletal muscle for $\mathrm{HB}^{15,16}$ or lentiviral vectors for transduction of HSPC for $\mathrm{HA}^{17}$ are being planned or ongoing, respectively; these will not be discussed here.

AAV-Based Gene Therapy: the Facts. AAV is a non-pathogenic, replication-deficient member of the parvovirus family. Naturally occurring wildtype (WT) AAV consists of a single-stranded DNA genome with two open reading frames flanked by inverted tandem repeats (ITRs). ${ }^{18}$ Binding of WT-AAV to heparan sulfate proteoglycans on the host cell allows uptake and,

\section{Basic Science Advances}

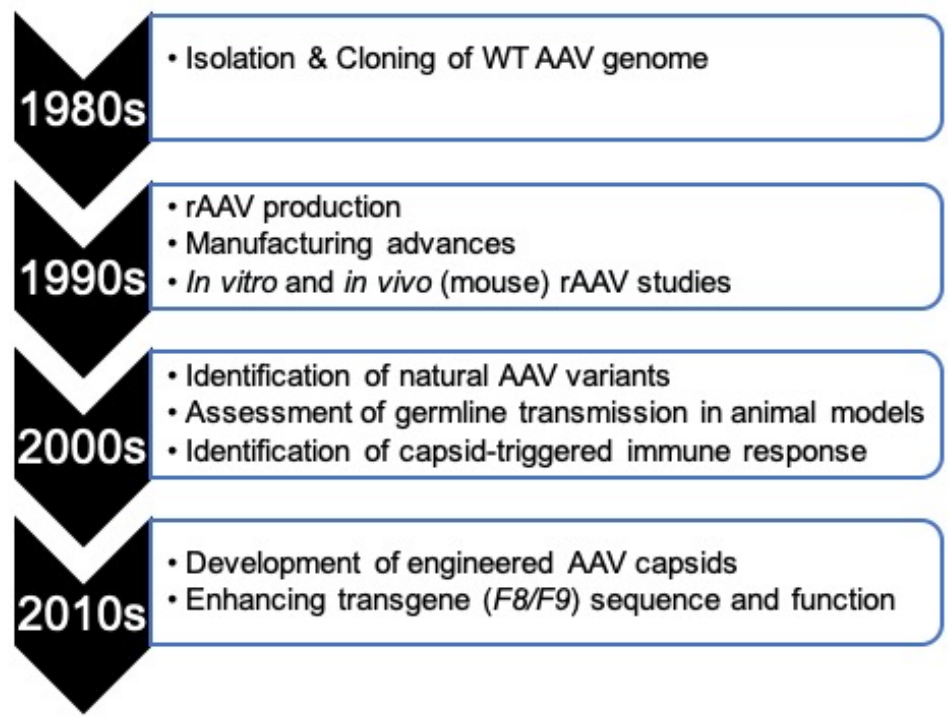

\section{Clinical Advances}

\section{- Preclinical success of long-term expression in small and large immunocompetent animal models}

- First in human FIX dosing (muscle-directed)

\section{- Phase I/II liver-directed hemophilia B clinical trials \\ - Identification of hepatocyte damage and loss of transgene expression}

\section{- Transient immunosuppression for cellular immune response \\ - Gain-of-function transgenes variants to $\downarrow$ vector dose \\ - Initiation and success of hemophilia A clinical trials \\ - Advanced phase clinical trials for hemophilia B}

Figure 1. Timeline of evolution of rAAV from basic science advances to clinical gene therapy. A significant body of basic science research allowed for translation from wildtype AAV to the recombinant AAV (rAAV) vectors used today. These included improvements in vector engineering and manufacturing, transgene optimization, and elucidating the immune response to rAAV in humans (as no preclinical model predicted this result). Further, laborious efforts in preclinical toxicity evaluation in the early 2000 's allowed clinical trials to advance rapidly in the 2000-2010s without requiring reassessment of these pharmacology/toxicology studies. Clinically, these data have allowed moving from the first-in-human trials in skeletal muscle to phase III trials for both hemophilia A and B with licensure expected in the near future. 
replication occurs following the entry into the host nucleus. Integration rates at the AAVS1 site of chromosome 19 (which requires a functional rep gene) vary from $45 \%$ in HeLa cells (aneuploid cells) to only $2.5 \%$ in diploid human fibroblast cells. ${ }^{19,20}$ In the rAAV vectors for hemophilia applications, the WT-AAV coding sequences are replaced with an $F 8$ or F9 transgene under control of a tissue-specific promoter and flanked by ITRs to allow packaging and production of the vector. Although the genomes of the rAAV vectors remain largely episomal ${ }^{21-24}$ as they lack the rep gene, rAAV vectors may integrate into the host DNA at other sites (reviewed in 24). Thus, the integration pattern and its potential implication for oncogenesis due to rAAV vectors differ from that of WT-AAV. Of the four currently available distinct rAAV production platforms suitable for scaling up vector production, ${ }^{25}$ two have been most commonly used for hemophilia gene therapy vectors. Hemophilia rAAV vectors to date have been produced via either transfection of mammalian cells with naked plasmid DNA or introduction of baculovirus expression vectors into Spodoptera frugiperda (Sf9) insect cells followed by cell lysis and purification via cesium chloride $(\mathrm{CsCl})$ gradient sedimentation or ion exchange chromatography. ${ }^{26-30}$ The capsid-determined tropism of the various AAV serotypes and promoter/enhancer elements used guide transgene production to the target tissue of interest. To date, in hemophilia, this has largely focused on liver-directed transgene expression under the control of a liver-specific promoters/enhancers that restrict expression to hepatocytes. ${ }^{31,32}$

Together, these distinct systems and advances have facilitated the use of rAAV vectors for gene therapy applications in hemophilia. Tables 1 and $\mathbf{2}$ summarize the multitude of rAAV-based gene therapy trials for hemophilia A and B, respectively. These contemporary trials are the product of decades of preclinical work and build on the successes and lessons learned from the early gene therapy studies in HB.

$A A V$ gene therapy for $H B$. Due to the packaging constraints of the rAAV genome, the pioneering rAAV hemophilia gene therapy studies were conducted in HB as the $F 9$ cDNA is $1.6 \mathrm{~kb}$ in size. ${ }^{33}$ The evolution of these early trials was guided by both advances in the basic understanding of rAAV and enhancements in vector production (Figure 1). The first-in-human rAAV F9 gene therapy trial utilized a ubiquitous cytomegalovirus (CMV) promoter/enhancer, and the rAAV2 serotype (rAAV2-CMV-F9-WT) injected into skeletal muscle and demonstrated safe and prolonged local, but not systemic, FIX expression. ${ }^{34,35}$ This expression was not hampered by either pre-existing neutralizing antibodies (NAbs) to rAAV2 or a postinfusion immune response to the vector and/or transgene. The excellent short and long-term safety profile of this trial motivated studies targeting the liver (as it is the natural site of FIX production). The trial sponsored by Avigen and Children's Hospital of Philadelphia (CHOP) of rAAV2- $F 9$ under control of a liver-specific promoter (rAAV2-hAAT-F9-WT) administered the vector via

Table 1. AAV hemophilia A clinical trials under the control of liver-specific promoter.

\begin{tabular}{|c|c|c|c|c|c|c|c|c|c|c|}
\hline Sponsor (ID) & Phase & Serotype & Cell Line & Transgene & $\begin{array}{c}\text { Dose } \\
\text { (vg/kg) }\end{array}$ & $\begin{array}{c}\text { Enrolled } \\
\text { (planned) }\end{array}$ & FVIII:C $C^{\infty}$ & $\begin{array}{l}\text { \# with } \\
\uparrow \text { ALT }\end{array}$ & $\begin{array}{l}\text { Follow- } \\
\text { up (yrs) }\end{array}$ & $\begin{array}{c}\text { NCT } \\
\text { Number }\end{array}$ \\
\hline \multirow{4}{*}{$\begin{array}{l}\text { Biomarin } \\
\text { ("BMN270") }\end{array}$} & \multirow{4}{*}{$\mathrm{I} / \mathrm{II}$} & \multirow{4}{*}{ AAV5 } & \multirow{4}{*}{ Insect } & \multirow{4}{*}{ coBDD-F8 } & $6 \times 10^{12}$ & 1 & $<1$ & $1 / 1$ & 3 & \multirow{4}{*}{02576795} \\
\hline & & & & & $2 \times 10^{13}$ & 1 & $<1$ & $0 / 1$ & 3 & \\
\hline & & & & & $4 \times 10^{13}$ & 6 & 7.9 & $4 / 6$ & 3 & \\
\hline & & & & & $6 \times 10^{13}$ & 7 & 16.4 & $6 / 7$ & 4 & \\
\hline \multirow{3}{*}{$\begin{array}{l}\text { Spark } \\
\text { ("SPK-8011") }\end{array}$} & \multirow{3}{*}{$\mathrm{I} / \mathrm{II}$} & \multirow{3}{*}{$\begin{array}{c}\text { AAV- } \\
\text { Spark200 }\end{array}$} & \multirow{3}{*}{ Mammalian } & \multirow{3}{*}{ coBDD-F8 } & $5 \times 10^{11}$ & 2 & $6.9-8.4$ & $0 / 2$ & $2-3$ & \multirow{3}{*}{03003533} \\
\hline & & & & & $1 \times 10^{12}$ & 3 & $5.2-19.8$ & $1 / 3$ & $2-3$ & \\
\hline & & & & & $2 \times 10^{12}$ & 7 & $<5-25$ & $5 / 7$ & $2-3$ & \\
\hline \multirow{4}{*}{$\begin{array}{l}\text { Pfizer } \\
\text { ("SB-525") }\end{array}$} & \multirow{4}{*}{$\mathrm{I} / \mathrm{II}$} & \multirow{4}{*}{ AAV6 } & \multirow{4}{*}{ Insect } & \multirow{4}{*}{ coBDD-F8 } & $9 \times 10^{11}$ & 2 & NR & $0 / 2$ & 2 & \multirow{4}{*}{03061201} \\
\hline & & & & & $2 \times 10^{12}$ & 2 & $1-2$ & $2 / 2$ & 2 & \\
\hline & & & & & $1 \times 10^{13}$ & 2 & $5-10$ & $0 / 2$ & 2 & \\
\hline & & & & & $3 \times 10^{13}$ & 5 & 64.2 & $4 / 5$ & $\sim 1$ & \\
\hline \multirow{3}{*}{$\begin{array}{l}\text { UCL/SJCRH } \\
\text { ("GO-8") }\end{array}$} & \multirow{3}{*}{$\mathrm{I}$} & \multirow{3}{*}{ AAV8 } & \multirow{3}{*}{ Mammalian } & \multirow{3}{*}{ coF8-V3 } & $6 \times 10^{11}$ & 1 & 7 & $1 / 1$ & 2 & \multirow{3}{*}{03001830} \\
\hline & & & & & $2 \times 10^{12}$ & 3 & $8-29$ & $1 / 2$ & $1-2$ & \\
\hline & & & & & $4 \times 10^{12}$ & 3 & $45-74$ & NA & $<1$ & \\
\hline \multirow{4}{*}{$\begin{array}{l}\text { Bayer } \\
\text { ("BAY2599023") }\end{array}$} & \multirow{4}{*}{$\mathrm{I} / \mathrm{II}$} & \multirow{4}{*}{ AAVhu37 } & \multirow{4}{*}{ Mammalian } & \multirow{4}{*}{ coBDD-F8 } & $5 \times 10^{12}$ & 2 & & & & \multirow{4}{*}{03588299} \\
\hline & & & & & $1 \times 10^{13}$ & 2 & $\begin{array}{l}\sim 3-10 \\
\sim 5-15\end{array}$ & $\begin{array}{r}0 / 2 \\
\mathrm{NA}\end{array}$ & $\begin{array}{c}1 \\
<1\end{array}$ & \\
\hline & & & & & $2 \times 10^{13}$ & 2 & $\begin{array}{c}\sim 5-15 \\
15-70\end{array}$ & NA & $\begin{array}{l}<1 \\
<1\end{array}$ & \\
\hline & & & & & $4 \times 10^{13}$ & (2) & $\sim 15-70$ & $2 / 2$ & $<1$ & \\
\hline $\begin{array}{l}\text { Baxalta/Shire } \\
\text { ("BAX 888") }\end{array}$ & $\mathrm{I}$ & AAV8 & Mammalian & coBDD-F8 & $\begin{array}{c}2 \times 10^{12} \\
6 \times 10^{12} \\
1.8 \times 10^{13} \\
\end{array}$ & $\begin{array}{l}2 \\
2\end{array}$ & NA & NA & NA & 03370172 \\
\hline
\end{tabular}

†Similar to AAV LK03 serotype [71]; ${ }^{\infty}$ last available FVIII activity data, chromogenic assay where available listed as range or median (if available).

AAV, adeno-associated virus; ALT, alanine aminotransferase; BDD, B-domain deleted; co, codon-optimized; FVIII, factor VIII; NA: not available, NAb: Neutralizing antibodies; NCT, national clinical trials; SJCRH, St. Jude Children's Research Hospital; UCL, University College of London. 
Table 2. AAV hemophilia B clinical trials under the control of a liver-specific promoter.

\begin{tabular}{|c|c|c|c|c|c|c|c|c|c|c|}
\hline Sponsor (ID) & Phase & Serotype & Cell Line & Transgene & $\begin{array}{c}\text { Dose } \\
(\mathrm{vg} / \mathrm{kg})\end{array}$ & $\begin{array}{c}\text { Enrolled } \\
\mathbf{n} \\
\text { (planned) }\end{array}$ & $\begin{array}{l}\text { FIX:C } C^{\infty} \\
\text { (median) }\end{array}$ & $\begin{array}{l}\text { \# with } \\
\uparrow \text { ALT }\end{array}$ & $\begin{array}{c}\text { Follow- } \\
\text { up } \\
\text { (years) }\end{array}$ & $\begin{array}{c}\text { NCT } \\
\text { Number }\end{array}$ \\
\hline Avigen/CHOP & $\mathrm{I} / \mathrm{II}$ & AAV2 & Mammalian & F9-WT & $\begin{array}{l}8 \times 10^{10} \\
4 \times 10^{11} \\
2 \times 10^{12}\end{array}$ & $\begin{array}{l}2 \\
3 \\
2\end{array}$ & $\begin{array}{l}<1 \\
<1 \\
<1\end{array}$ & $\begin{array}{l}0 / 2 \\
1 / 3 \\
1 / 2\end{array}$ & $12-15$ & 00076557 \\
\hline SJCRH/UCL & I & AAV8 & Mammalian & co-sc-F9-WT & $\begin{array}{l}2 \times 10^{11} \\
6 \times 10^{11} \\
2 \times 10^{12}\end{array}$ & $\begin{array}{l}2 \\
2 \\
6 \\
\end{array}$ & $\begin{array}{l}1.4-2.2 \\
2.1-2.9 \\
2.9-7.2\end{array}$ & $\begin{array}{l}0 / 2 \\
0 / 2 \\
4 / 6 \\
\end{array}$ & 8 & 00979238 \\
\hline $\begin{array}{l}\text { uniQure } \\
\text { (AMT-060) }\end{array}$ & $\mathrm{I} / \mathrm{II}$ & AAV5 & Insect & coF9-WT & $\begin{array}{l}5 \times 10^{12} \\
2 \times 10^{13}\end{array}$ & $\begin{array}{l}5 \\
5\end{array}$ & $\begin{array}{c}1.3-8.2(5.3) \\
3.9-11.1(7.1)\end{array}$ & $\begin{array}{l}1 / 5 \\
2 / 5\end{array}$ & 4 & 02396342 \\
\hline $\begin{array}{l}\text { Spark } \\
\text { ("Spark-9001") }\end{array}$ & $\mathrm{I} / \mathrm{II}$ & Spark-100 & Mammalian & coF9-Padua & $5 \times 10^{11}$ & 10 & $14-81(29.5)$ & $2 / 10$ & $>3$ & 02484092 \\
\hline $\begin{array}{l}\text { Shire } \\
\text { ("BAX 335") }\end{array}$ & $\mathrm{I} / \mathrm{II}$ & AAV8 & Mammalian & $\begin{array}{l}\text { co-sc-F9- } \\
\text { Padua }\end{array}$ & $\begin{array}{l}2 \times 10^{11} \\
1 \times 10^{12} \\
3 \times 10^{12} \\
\end{array}$ & $\begin{array}{l}2 \\
4 \\
2 \\
\end{array}$ & $\begin{array}{c}3.5^{*} \\
12.0^{*} \\
45^{*} \\
\end{array}$ & $\begin{array}{l}\text { NA } \\
\text { NA } \\
2 / 4 \\
\end{array}$ & $>2.5$ & 01687608 \\
\hline $\begin{array}{l}\text { Uniqure } \\
\text { (AMT-061) }\end{array}$ & $\mathrm{IIb}$ & AAV5 & Insect & coF9-Padua & $2 \times 10^{13}$ & 3 & $\begin{array}{c}31.3-50.2 \\
(40.8) \\
\end{array}$ & $0 / 3$ & $1-2$ & $03489291^{\Delta}$ \\
\hline $\begin{array}{l}\text { Freeline } \\
\text { ("FLT180a") }\end{array}$ & $\mathrm{I} / \mathrm{II}$ & AAVS3 & Mammalian & coF9-Padua & $\begin{array}{c}4.5 \times 10^{11} \\
7.5 \times 10^{11} \\
9.75 \times 10^{11} \\
1.5 \times 10^{12}\end{array}$ & $\begin{array}{l}2 \\
2 \\
4 \\
2\end{array}$ & $\begin{array}{c}37-38 \\
2-60 \\
57-139 \\
90-253\end{array}$ & $\begin{array}{c}0 / 2 \\
2 / 2^{\phi} \\
1 / 2^{\phi} \\
2 / 2^{\phi}\end{array}$ & $\begin{array}{c}2 \\
1 \\
<1 \\
<1\end{array}$ & 03369444 \\
\hline $\begin{array}{l}\text { Dimension } \\
\text { ("DTX 101") }\end{array}$ & $\mathrm{I} / \mathrm{II}$ & AAVrh10 & Mammalian & coF9-WT & $\begin{array}{c}1.6 \times 10^{12} \\
5 \times 10^{12}\end{array}$ & $\begin{array}{l}3 \\
3 \\
\end{array}$ & $\begin{array}{c}1.67 \\
22.47 \\
\end{array}$ & $\begin{array}{l}\text { NA } \\
3 / 3<\end{array}$ & $<1$ & 02618915 \\
\hline
\end{tabular}

${ }^{\infty}$ last available reported data, aPTT based clot assay values; *median peak FIX values, only two patients with sustained FIX activity beyond 1 year[50]; ${ }^{\phi}$ patients required additional immunosuppression despite prophylactic steroids; ${ }^{\Delta}$ trial includes patients with neutralizing antibodies to AAV5

AAV, adeno-associated virus; ALT, alanine aminotransferase; co, codon-optimized; FIX, factor IX; NA: not available, NCT, national clinical trials; SJCRH, St. Jude Children's Research Hospital; UCL, University College of London

the hepatic artery in 7 subjects (Table 2). ${ }^{36}$ The low and mid-dose cohorts were intentionally subtherapeutic. In the high dose cohort $\left(2 \times 10^{12} \mathrm{vg} / \mathrm{kg}, \mathrm{n}=2\right)$, pre-existing anti-rAAV2 NAbs did preclude transgene expression in one subject, in contrast to the prior skeletal muscle trial. ${ }^{35}$ Another high-dose treated patient initially achieved a FIX level of $11 \%$ but lost FIX activity concurrent with a transient rise in alanine aminotransferase (ALT) and aspartate aminotransferase (AST) levels, markers of hepatocyte damage. After several attempts by many groups to develop preclinical models to understand this phenomenon, it became clear that such a complication is observed only in humans.

After consultation with regulatory agencies, another subject (Subject G) was dosed with subtherapeutic vector at $4 \times 10^{11} \mathrm{vg} / \mathrm{kg}$ with a planned longitudinal collection of peripheral blood mononuclear cells (PBMCs) to test for potential cellular immune responses to the two neoantigens (rAAV capsid protein and FIX) using a sensitive and specific technique, the interferon$\gamma \quad($ IFN $\gamma)$ enzyme-linked immunosorbent spot (ELISPOT). These studies suggested that the underlying mechanism of this toxicity is likely a cytotoxic $\mathrm{T}$ cellmediated immune response against the vector capsid sequences displayed on hepatocytes with resultant loss of transduced cells and consequent constraint on transgene expression. There was no evidence of cellular immune responses to FIX. There was, however, a temporal association between the expansion of the rAAV2-capsid cellular response, and a rise in the liver

\section{enzymes (ALT/AST). ${ }^{37}$}

These data guided the third defining HB trial, led by St. Jude Children's Research Hospital (SJCRH) and University College of London (UCL), which used rAAV8-LP1-F9-WT at escalating doses in 10 men with HB. ${ }^{38,39}$ This study was the first to 1 ) infuse an $F 9$ vector via a peripheral vein (which was made possible by the strong liver tropism of AAV8 compared to AAV2) and 2) demonstrate that initiating prednisone within 48 hours of noting a rise in ALT or drop in FIX could limit the loss of FIX expression in vector-infused patients. Further, this trial supported the dose-dependency of the cellular immune response to the capsid as none of the patients in the low $(n=2)$ or intermediate $(n=2)$ dose cohorts demonstrated an ALT rise (Table 2), whereas 4 of 6 subjects $(66 \%)$ in the high dose cohort showed evidence of a cellular immune response. Over 8 years of follow-up, these high-dose subjects have maintained FIX levels of 2.9-7.2\% (Table 2). ${ }^{40}$

These studies imparted two critical lessons. First, patients with neutralizing antibodies against the AAV serotype should be excluded to avoid the inhibitory effect on gene expression. Second, as there are no biomarkers that predict the onset of rAAV capsidmediated cellular response, close monitoring of liver enzymes and factor levels should be used as surrogate markers for the ongoing cellular responses in real-time. Although ELISPOT assays are the most accurate for the diagnosis of $\mathrm{T}$ cell responses, the turn-around time of the assay is not ideal due to the need for rapid initiation of 
therapeutic intervention to stop or control the loss of transduced cells and transgene expression. Consequently, current clinical trials use the ALT as a biomarker of potential capsid-directed cellular immune response and a hallmark of liver damage; ALT is more sensitive to hepatocyte damage than AST and has a longer half-life. ${ }^{41}$

These studies paved the way for the trial sponsored by Spark Therapeutics, which leveraged the hyperactive F9 variant, F9-Padua, with the goal to decrease the therapeutic vector dose while increasing transgene activity ${ }^{42}$ F9-Padua results in an arginine to lysine substitution at position 338 in the FIX protein and has a specific activity (activity to antigen ratio) of $>8{ }^{43}$ Thus, even small amounts of FIX antigen can provide hemostatically normal FIX activity without increasing the risk of thrombosis ${ }^{44-46}$ compared to FIX-WT. A trial of 10 subjects injected with $5 \times 10^{11} \mathrm{vg} / \mathrm{kg}$ of $\mathrm{rAAV}$ Spark100-F9-Padua resulted in sustained FIX activity of $\sim 30 \%$ of normal over multiple years of follow-up and only $2 / 10(20 \%)$ subjects required prednisone therapy for a capsid-mediated immune response, which correlated with a rise in ALT and decline in the FIX activity ${ }^{47}$ Despite decreasing the vector dose 4 -fold, a mean FIX activity of $30 \%$ was achieved, which is $\sim 15-$ fold higher than with FIX-WT at a similar dose in the SJCRH trial (Figure 2). It should be noted that in the Shire-sponsored rAAV8-F9-Padua trial, loss of transgene expression in the high dose cohort $\left(3 \times 10^{12}\right.$ $\mathrm{vg} / \mathrm{kg}$ ) could not be rescued in all patients, ${ }^{48-50}$ which may be due to higher vector doses and/or differences in vector content including $\mathrm{CpG}$ islands. ${ }^{51,52}$

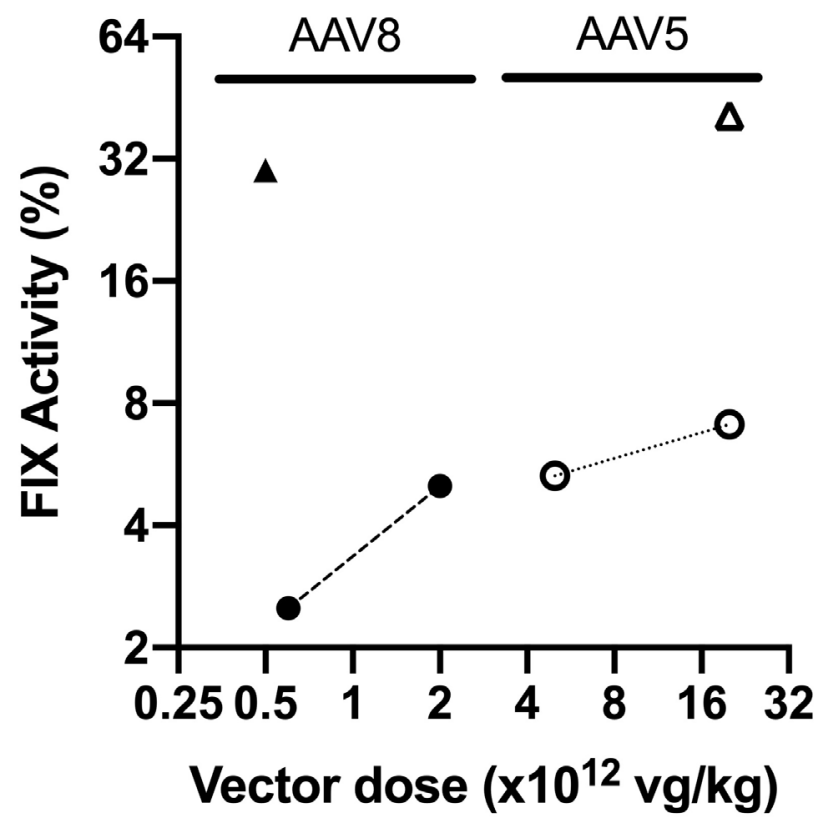

Figure 2. Hemophilia B trial efficacy using F9 WT versus Padua transgenes. Mean FIX activity is significantly higher using F9Padua (triangles) compared to F9-WT (circles) irrespective of AAV8 (closed symbols) or AAV5 (open symbols) vector serotype. Data derived from values listed in Table 2 .
Data from the Freeline sponsored trial using a novel serotype with liver tropism (AAVS3) encoding F9Padua has recently been presented across four cohorts from $4.5 \times 10^{11}$ to $1.5 \times 10^{12} \mathrm{vg} / \mathrm{kg}$. All patients received prophylactic steroids with varying initiation times, depending on the cohort. In the lowest dose group, there was no transaminitis, and FIX levels showed an increase while on steroids with plateau levels at 2 years of $37-$ $38 \%{ }^{53,54}$ However, the initial plan to scale up to $1.5 \mathrm{x}$ $10^{12} \mathrm{vg} / \mathrm{kg}$ resulted in safety concerns such as transaminitis in both subjects, which required methylprednisolone and tacrolimus to control. One subject expressing supra-therapeutic FIX levels (peak $520 \%$ ) developed a local thrombotic complication at an arteriovenous fistula when weaned off prophylactic anticoagulation. ${ }^{55,56}$ Consequently, the trial suspended this dose, and two additional intermediate-dose cohorts were tested (Table 2). All subjects received prophylactic steroid therapy, and tacrolimus was added to control transaminitis either therapeutically or prophylactically. Therapeutic levels of FIX were achieved in both cohorts in a dose-dependent manner (the relatively short follow-up period prevents firm efficacy conclusions at this point).

The uniQure-sponsored trials have utilized an Sf9 insect cell line and baculovirus production system to develop the rAAV5-LP1-F9 cDNA therapy platform encoding either FIX-WT (AMT-060) ${ }^{57}$ or FIX-Padua (AMT-061). ${ }^{58,59}$ A potential advantage of rAAV5 is the possibility of a lower prevalence of NAbs in the general population compared to the other AAV serotypes and/or lower avidity of anti-AAV5 NAbs. ${ }^{60,61}$ It should be noted that there is a wide range in the reported prevalence of NAbs to AAV, including AAV5, in the general and hemophilia populations due to variability in geographic origin of populations $\mathrm{s}^{62-65}$ but also likely from differences in the assay techniques. Data from uniQure's porphyria gene therapy trial of rAAV5 at $5 \times 10^{11}-1.8$ x $10^{13} \mathrm{vg} / \mathrm{kg}$ demonstrated a lack of capsid-triggered immune response at those doses; albeit none of the patients had therapeutic transgene levels either. ${ }^{66}$ In the AMT-06, 0 trial, 1/5 in the low dose, and 2/5 in the high dose group $\left(2 \times 10^{13} \mathrm{vg} / \mathrm{kg}\right)$ had a transient rise in ALT (with onset ranging from 3 to 10 weeks). Still, there was no detectable capsid-mediated cellular immune response as measured by IFN- $\gamma$ ELISPOT assay (the commonly used surrogate for cellular immunotoxicity) or decrease in FIX levels. ${ }^{57}$ The reason for this transient increase in ALT remains unclear, although alcohol consumption and/or antibiotic use were postulated as modulators, in part, of the liver damage. These three patients received steroid therapy, but its therapeutic role is not clear. The median FIX levels in the high dose cohort were $7.1 \%$ compared to $5.3 \%$ in the low-dose cohort (4-fold lower dose) over 4 years of follow-up, suggesting a lack of clear linear dose-response (Figure 2). In the three patients treated with AMT-061 (encoding F9-Padua) at 
$2 \times 10^{13} \mathrm{vg} / \mathrm{kg}$, mean FIX activity is similar to the Spark trial with the same transgene at about $40 \%,{ }^{58}$ but at 40 fold higher dose. As there was seemingly no correlation between the presence of NAbs to rAAV5 and FIX transgene expression in AMT-060, ${ }^{61}$ candidates with anti-AAV5 NAbs were not excluded from AMT-061, and the titers of the first three patients are between 1:25 and 1:48. ${ }^{59}$ However, this is a preliminary finding, and further assessment of the detection of NAbs and the ability of rAAV5 to overcome the presence of preexisting NAbs is necessary.

Early phase rAAV-based gene therapy for $\mathrm{HB}$ has reached critical mass, providing a firm basis for current phase III clinical trials. Collectively, FIX-Padua across distinct rAAV trials has not shown increased immunogenicity or spontaneous thrombosis, which is consistent with preclinical data in inhibitor-prone HB dogs. ${ }^{45,46}$ However, as seen in Figure 2, there is a significant variation in the vector dose required to attain similar FIX levels. Of note, the transgenes used in the rAAV5 trials were also used in the rAAV2 and rAAV8 trials. Thus, F9 transgene is unlikely to influence these discrepancies in therapeutic vector doses. The differences in serotype, manufacturing process, posttranslational modification of the vector, or combination thereof may be responsible for this discrepancy. A sideby-side comparison of these vector production systems is highly desirable.

AAV Gene Therapy for HA. Although HA is more prevalent than $\mathrm{HB}$, the generation of $\mathrm{rAAV}$ vectors that could efficiently accommodate the $F 8$ cDNA $(7 \mathrm{~Kb})$ was challenging due to the limited capacity of the AAV genome at $4.7 \mathrm{~kb}$. Modifications to the $F 8$ transgene evolved over time. First, the B domain was truncated from $>900$ to 14 amino acids as it is not required for full procoagulant activity of FVIII; ${ }^{67}$ however, this was not sufficient to allow cloning into rAAV vectors. Subsequently, a series of modifications in the vector design, such as the generation of minimally sized effective liver-specific promoters, enhancers, and other regulatory elements allowed the generation of rAAV vectors that expressed FVIII. Finally, the field developed codon-optimized (co) B-domain deleted (BDD)-F8 transgene(s) resulting in higher FVIII expression levels without modifications to the amino acid sequence or need for additional space in the transgene.

Several phase I and II HA trials are reporting therapeutic FVIII levels (Table 1) in the moderate (1$5 \%)$ or mild $(>5 \%)$ hemophilia ranges. The vector that is the furthest along the developmental pipeline for HA is Biomarin's BMN-270, which is a rAAV5 vector carrying a co- $B D D-F 8$ transgene. ${ }^{68,69}$ In the high vector dose cohort $\left(6 \times 10^{13} \mathrm{vg} / \mathrm{kg}\right)$, median chromogenic FVIII levels were $55 \%$ (range $11-95 \%$ ) in the first year after treatment but, surprisingly, declined over the ensuing four years to $16.4 \%$ (Figure 3A).$^{70}$ Given that there was initially a dramatic increase in FVIII activities, Biomarin also conducted a trial at an intermediate dose cohort $\left(4 \times 10^{13} \mathrm{vg} / \mathrm{kg}\right)$. The median chromogenic FVIII activity at year 1 for $5 / 6$ subjects was $24 \%$ (one subject had levels $<3 \%$ ) and over 3 years has declined to $7.9 \%$ (Figure 3A) ${ }^{70}$ The one-stage FVIII activity in these subjects was about 1.6-fold higher than their chromogenic activities (Figure 3B). In the high dose cohort, following a rise in ALT in the first patient, all subsequent subjects received prophylactic prednisone. Despite this, all patients still developed a rise in ALT between weeks 3-28, and there was no clear correlation
A

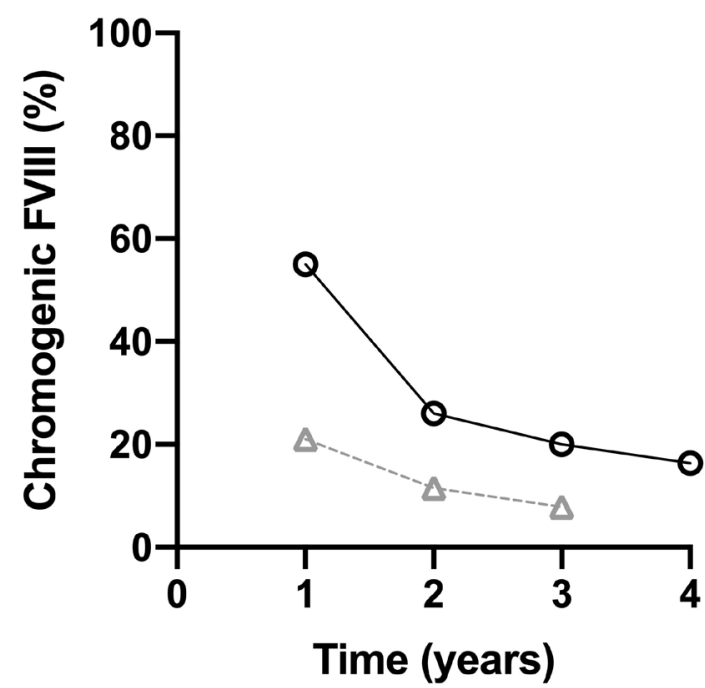

B

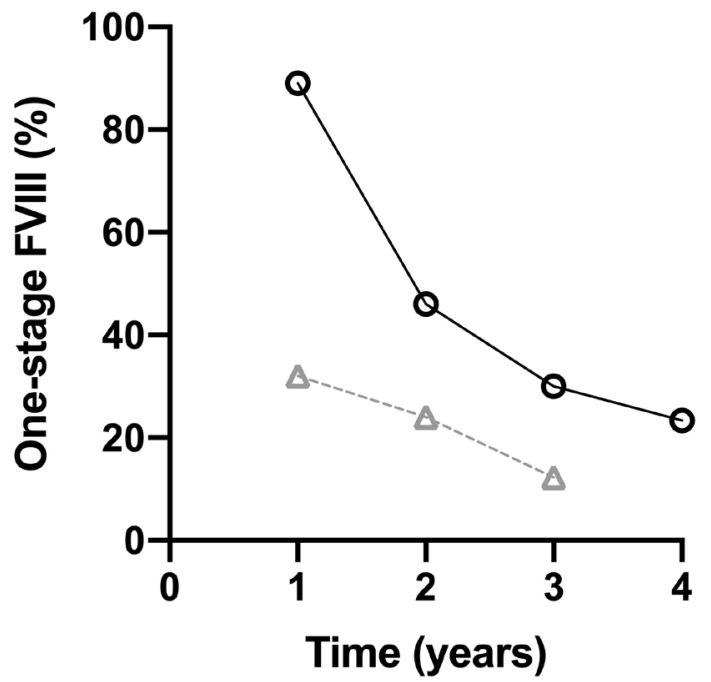

Figure 3. Longitudinal FVIII activity following rAAV5-F8 infusion in human subjects. A) Median chromogenic FVIII activity over time in the high dose $\left(\mathrm{O}, 6 \times 10^{13} \mathrm{vg} / \mathrm{kg}\right)$ cohort declined from a median of $55 \%$ to $16.4 \%$ over four years of follow-up compared to the intermediate dose cohort $\left(\triangle, 4 \times 10^{13} \mathrm{vg} / \mathrm{kg}\right)$ where levels declined from a median of $21 \%$ to $7.9 \%$ over three years of follow-up. B) Median one-stage assay based FVIII activity over time in the $6 \times 10^{13}(\mathrm{O})$ and $4 \times 10^{13}(\triangle) \mathrm{vg} / \mathrm{kg}$ rAAV5- $F 8$ dose cohorts. 
between ALT improvement, FVIII activity, and IFN $\gamma$ ELISPOT results. ${ }^{69}$

In the Spark Therapeutics trial of AAVSpark200$\operatorname{co} B D D-F 8$ (similar to AAV serotype LK03) ${ }^{71}$ within the high dose cohort $\left(2 \times 10^{12} \mathrm{vg} / \mathrm{kg}\right)$, five of seven subjects received steroids for either an increase in ALT, declining FVIII levels, or a positive ELISPOT. Of these, two experienced loss of FVIII activity that could not be rescued with prednisone or methylprednisolone with levels falling below $5 \% .^{72,73}$ In contrast, one subject in the mid-dose cohort $\left(1 \times 10^{12} \mathrm{vg} / \mathrm{kg}\right)$ had a rise in ALT, and two of three had a decrease in FVIII (treated with steroids) without an increase in ALT or positive IFN $\gamma$ ELISPOT. All three have maintained levels of $\sim 5-20 \%$. In the low dose group, neither patient had a rise in ALT or loss of FVIII and have maintained levels of $\sim 7-8 \%$. The UCL-SJCRH sponsored GO-8 trial (rAAV8- $F 8$ $V 3)$, utilizing a hyperactive FVIII variant $(F 8-V 3)$ with amino acid insertions into the residual $\mathrm{B}$ domain sequence,$^{74}$ demonstrated elevated ALT in two subjects at the low and mid-dose cohorts $\left(6 \times 10^{11}\right.$ and $2 \times 10^{12}$ $\mathrm{vg} / \mathrm{kg}$, respectively) which resolved with prednisone but was not associated with a loss of FVIII activity. ${ }^{75}$

In comparison to these mammalian cell line vectors, the Biomarin trial utilizing an $\mathrm{Sf} 9$ insect cell line and baculovirus production system-derived vector required a higher vector dose to achieve therapeutic FVIII levels. For comparison, the low dose cohorts $\left(6 \times 10^{12}\right.$ and $2 \times$ $10^{13} \mathrm{vg} / \mathrm{kg}$ ) in the Biomarin trial demonstrated $<1-2 \%$ FVIII activity $(\mathrm{n}=1$ per cohort) whereas a log-fold lower dose of $2 \times 10^{12} \mathrm{vg} / \mathrm{kg}$ in the Spark and UCL/SJCRH trials did result in measurable FVIII activity in the mild hemophilia range for those without an immune response. In a recent publication, the authors argue that the initial delay in achieving plateau FVIII activity levels with rAAV5- $F 8$ is since the transgene is slightly larger than the vector's packaging capacity and, as the positive and negative DNA strands of the transgene are on separate virions, the full-length functional transcripts take longer to assemble than with other trials ${ }^{68}$ but their findings do not clearly support this. Further, preclinical studies in mouse and canine models with rAAV $2^{76}$ or rAAV $8^{77}$ carrying the $F 8$ gene split between two vectors (rAAV vectors carrying the light or heavy chain) delivered simultaneously resulted in similar kinetics of expression to single-chain FVIII. The unexpected loss of transgene activity over time is also unusual in the context of rAAV liver gene therapy. The authors argue that this is due to the turnover of nucleated cells carrying stable full-length episomes, as measured by sequencing analysis of PBMCs; again, these claims are highly speculative at this point. ${ }^{68}$

The decline over time in FVIII levels seen in these subjects in the Biomarin trial has not been observed in the uniQure rAAV5-F9-WT trial over 4-years of followup despite a 3-fold lower vector dose compared to the Biomarin trial. ${ }^{78}$ Further, the FIX expression in ten men with HB injected with rAAV8-F9-WT is stable over an extended period of $\sim 8$ years. ${ }^{40}$ Thus, the underlying mechanism of this loss of FVIII transgene expression remains unclear; a combination of vector dose, vector manufacturing, and transgene might impact the stability of the expression levels. At this time, it is too early to identify the best performing rAAV system for HA and long term follow up studies will be required to determine the efficacy of any given strategy.

AAV-Based Gene Therapy: the Quandaries. These significant advances in gene therapy for hemophilia make it likely to enter the clinics in the coming years. There have been no sustained adverse events documented in these trials with follow-up periods ranging from $<3$ years to more than 7 years with ongoing observations. However, questions remain about (1) target factor level and durability of response, (2) long-term follow-up requirements, (3) the risk of genotoxicity, (4) expanding patient eligibility to inhibitor patients and pediatric population, and (5) how to price and pay for gene therapy.

1) Therapeutic transgene expression target and durability of response. Initially, the goal in gene therapy trials was to bring factor levels over the $1 \%$ necessary to convert a patient from severe to moderate bleeding phenotype. In some subjects in the SJCRH/UCL and uniQure HB trials, FIX levels of $<3 \%$ were not sufficient to prevent joint pain and bleeds, and prophylaxis was necessary. ${ }^{38,39,57}$ Further, higher levels are likely required to prevent joint bleeds and stop prophylaxis, as noted by a Dutch pediatric HA study that showed levels $>12 \%$ were necessary to prevent joint bleeds. ${ }^{79}$ A larger U.S.-based study of adult and pediatric nonsevere HA and HB patients estimated that FVIII or FIX levels $>20 \%$ of normal would be needed to prevent hemarthrosis in individuals 25-44 years of age, the typical age of subjects enrolled in early phase gene therapy trials. ${ }^{80}$ On the other hand, elevated FVIII $(>150 \mathrm{IU} / \mathrm{dL})$ or FIX $(>129 \mathrm{IU} / \mathrm{dL})$ levels are associated with increased risk for thrombosis compared to the general population. ${ }^{81-85}$ Thus, true target FVIII or FIX activity remains debatable. ${ }^{86}$

Understanding the optimal transgene level is essential as the target FVIII or FIX level may affect the choice of vector dose. Recent trials have used fixed doses for all enrolled patients irrespective of underlying joint status or bleeding history. Prior studies have noted variability in bleeding phenotype in patients with severe hemophilia. ${ }^{87,88}$ As vectors move from trials to clinical practice, it may be important to consider these modifiers in choosing the appropriate dose for each patient. The dose will need to be carefully balanced against the risk of liver toxicity due to a cellular immune response to the capsid (or unknown mechanisms). ${ }^{89}$ At this point, the dose-dependent cellular immune response to the vector 
capsid does not correlate with the rise in ALT with insect cell-line derived rAAV5 vectors. Whether this relationship will hold true in the ongoing mammalian vector HA trials is unknown.

2) Long term follow-up requirements. Gene therapy trials to date have typically been very selective in their eligible population. For accurate assessments of both efficacy and safety of a given strategy, long-term follow-up of these subjects is necessary prior to and after approval of a product. Although the vector infusion is given only once, patients will need to be followed for recognition of potential unexpected findings, given the lack of preclinical models that recapitulate the transient liver toxicity due to cellular immune response to vector in humans. In contrast to the loss of transgene activity in the BMN-270 trial, increasing gene expression has been seen in long-term follow-up of a canine HA model,${ }^{90}$ the reasons for these discrepancies continue to be determined. Further, previous retroviral and AAV studies using a CMV promoter in mice and dogs were complicated by gene silencing events of transgene expression; ${ }^{91,92}$ this has not been reported with the use of liver-specific promoters.

In addition, adjustments of FVIII or FIX levels may be necessary to accommodate for a subject's physical activity and/or joint status (although vector readministration at this point is not feasible). Similarly, major trauma or surgery will also require close monitoring and likely transient replacement therapy with factor concentrates. The development of neutralizing alloantibodies ("inhibitors") to FVIII or FIX following gene therapy is an unlikely scenario. ${ }^{45,46,77,93,94}$ Still, little is known about subjects with minimal exposure to factor concentrates prior to enrollment in rAAV clinical trials wherein selected persons had $>20$ exposure days.

Finally, the risk of germline transmission of viral vectors is a major safety concern. To date, gene therapy has been somatic in nature, and preclinical studies were required by regulatory agencies prior to human trials. ${ }^{95,96}$ These did not show AAV in the semen of rabbits or dogs receiving rAAV by intramuscular or portal vein injections, respectively. ${ }^{97}$ However, subjects in the rAAV2 trial did have transient detection of vector sequences in the semen. ${ }^{36,98,99}$ Subsequent studies in rabbits using intravascular delivery of rAAV vectors were associated with transient detection of a vector in semen in a dose-dependent manner. ${ }^{100,101}$ In addition, evidence supported the concept that vector shedding into the semen did not require germ cells, as the semen of vasectomized rabbits (i.e., lacking germ cells) transiently contained vector sequences. ${ }^{100}$ Although vector shedding in the majority of the rAAV serotypes tested to date seem consistent with these findings, the risk, if any, of inadvertent dissemination of vector to germ cells needs to be determined after the development of other natural or engineered rAAV vectors as these results may vary due to vector and/or production platforms. The advice of the regulatory agencies is to use barrier contraception while the semen contains rAAV particles. ${ }^{102}$

3) Risk of genotoxicity. In evaluating the safety in terms of potential genotoxicity due to rAAV vectors, it is important to note that the recombinant AAV vector only rarely integrates into the host DNA, whereas the WTAAV may exhibit latent infection via integration events mediated by the rep gene. Thus, the rate and pattern of integration and risk of insertional mutagenesis differ from the WT-AAV. Recombinant AAV vectors are poorly integrating vectors with no preferential specific sites. For rAAV, integration events, if any, occur at diverse locations depending on the experimental model. Thus, findings from WT-AAV studies are not directly relevant to rAAV vectors. Moreover, in some in vitro experimental models, WT-AAV2 may, in fact, protect against tumor formation. ${ }^{103,104}$ Nevertheless, over the years, sporadic reports on the risk of AAV integration and increased risk of tumor formation raised safety concerns, particularly for genetic diseases with a long life-expectancy such as hemophilia.

In 2001, animal studies using rAAV in neonatal mice with MPS VII, with a high vector dose and a strong enhancer element, demonstrated some integration, which led to hepatocellular carcinoma (HCC). ${ }^{105,106}$ Upon discussion with various investigators and regulatory agencies, trials using rAAV vectors for genetic disease were continued but with a commitment to long-term follow up of the subjects who received a direct injection of the vector for $\sim 15$ years. Some of these studies of rAAV liver gene therapy were presented at scientific meetings, and early evaluation did not show evidence of increased risk of tumor formation. ${ }^{98}$ Subsequently, in 2007, a more detailed examination of the molecular evolution of the HCC in neonatal mice showed that integration occurred largely at a miRNA site or the Rian locus, which is transcriptionally active in neonatal but not adult mice. This locus is absent in vertebrates except for mice and rats. ${ }^{104}$ Additional studies in adult rodents, dogs, and non-human primates could not confirm the increased risk of tumor formation by rAAV vectors. ${ }^{107-112}$ These risks can further be mitigated by modulating vector (dose, promoter, enhancer) and subject (age, target tissue) characteristics. ${ }^{113}$ Interestingly, the vector constructs adapted for several clinical studies for rAAV liver gene therapy seems to be associated with the least, if any, risk of tumor formation in mouse models. ${ }^{113}$

In 2015, Nault and colleagues showed the integration pattern of WT-AAV in human subjects using a series of tissues from HCC affected and normal areas. ${ }^{114}$ In brief, only 11/193 samples showed the integration of AAV in potential genes associated with HCC, but samples were 
also positive for viral hepatitis and alcoholic liver disease, and this study lacked data from healthy controls. These findings were again informative of WT-AAV biology but are not necessarily applicable for rAAV used in gene therapy. ${ }^{103,115,116}$

In 2017, Logan and colleagues found that an early rAAV2 vector retained a small WT-AAV2 sequence in the 3' untranslated region (UTR) adjacent to the ITR (derived from AAV2 and used in most rAAV constructs) which contains a binding site of hepatic transcription factors (including HNF1- $\alpha$ ). ${ }^{117}$ This retained sequence can enhance transcription from the transgene promoter in human hepatocytes and rodent livers. Further, this sequence is captured within the 163nucleotide frequent insertion region of the WT-AAV2 genome that has been implicated in HCCs. However, there is no definitive proof of insertional gene dysregulation by this sequence. Emerging data presented only in abstract form of HA dogs injected with rAAV carrying canine $F 8$ showed integration events but without malignant transformation in necropsy samples; the implications of these findings are still unclear. ${ }^{90}$ In addition, to date, numerous patients with hemophilia have been treated with rAAV liver-directed gene therapy with no reported significant safety or toxicity concerns; ${ }^{36,38,39,42,49,57,69,118}$ long-term data is still being accumulated.

Overall, the likelihood of genotoxicity with rAAV liver-directed gene therapy is likely low. It merits mention that in the $>140$ rAAV gene therapy trials targeting a variety of tissues, none have reported oncogenesis. Although WT-AAV infection may be associated with HCC, the risk of rAAV mediated HCC is currently restricted to integration events into a murine-only genetic locus that is active in neonatal mice. However, as shown by recent studies, certain vectors may integrate into the genome indiscriminately. Of note, the long-term follow-up of subjects from the $\mathrm{CHOP} /$ Avigen rAAV2-F9 trial at 12-15 years did not show evidence of tumors via measurement of tumor markers or liver enzymes..$^{98,119}$

Current guidelines from the Food and Drug Administration (FDA) and European Medicines Agency (EMA) recommend a 5-year follow-up period for nonintegrating gene therapy vectors, ${ }^{102,120}$ such as rAAV, as opposed to prior guidelines which recommended 15 years. The rationale for this shorter term of follow-up may no longer be applicable, especially given the unprecedented fall in FVIII expression from the rAAV5F8 trial over 4 years of ongoing observation. Further, the coupling in recent trials of gene therapy with immunosuppressive regimens that could modify safety and long-term complications also raises concerns. Consequently, long-term clinical follow-up of patients from these early trials should be undertaken to help inform the safety and efficacy of liver-directed rAAV gene therapy in patients.
4) Expanding patient eligibility. The next step in advancing gene therapy should be to allow for the expansion of the target patient population to those who could benefit from the recent advances in gene therapy. This includes patients historically ineligible for gene therapy trials, including those with inhibitors, patients $<$ 18 years of age or who have fewer factor exposure days, and those with NAbs to AAV serotypes.

4a) Patients with current or prior history of inhibitors to FVIII or FIX. Due to the theoretical concern that gene therapy may increase the risk of inhibitor formation, early phase clinical trials have excluded patients with current inhibitors or a history of inhibitors to FVIII or FIX. To date, data from both HA and HB subjects have not shown any evidence of inhibitor development following gene therapy. AAV liver-directed gene therapy in canine models of HA and HB demonstrate a favorable bias towards inducing immune tolerance to canine FVIII or FIX in inhibitor-prone HA ${ }^{77}$ and HB dogs, ${ }^{110,121}$ respectively. Our laboratory has shown great promise for gene therapy to provide the dual function of inducing immune tolerance to eradicate inhibitors and provide lifelong endogenous prophylaxis in large animal models of hemophilia $\mathrm{A}^{93}$ and $\mathrm{B} .{ }^{45}$ These preclinical studies suggest that the liver-restricted endogenous expression of FVIII or FIX allows for the induction of immune tolerance, at least in part in the HA models, by the upregulation of a regulatory $\mathrm{T}$ cell pool. ${ }^{93}$ Thus, the possibility of using rAAV liver gene therapy for inhibitor eradication would open a new therapeutic avenue to fulfill an unmet medical need. Inhibitor eradication via immune tolerance induction (ITI) regimens is costly, prone to catheter-related thrombotic and infectious complications in pediatric patients, ${ }^{122}$ and is successful in $60-70 \%$ of patients with good prognostic risk. ${ }^{123}$ In order to maintain tolerance, modern-day practice is to continue factor prophylaxis 2-3 times per week. The use of emicizumab as a prophylactic hemostatic regimen for inhibitor and non-inhibitor HA patients is now largely accepted; ${ }^{5,6}$ however, treatment of breakthrough bleeding episodes still requires bypassing agents or FVIII therapy in these patients, respectively. The use of prothrombin complex concentrates in some patients has been associated with thrombosis. ${ }^{11}$ However, the desired outcome of standard ITI is the normalization of the hemostatic response to FVIII to avoid bypassing agent therapy and this forms the motivation for definitive inhibitor eradication in inhibitor patients; gene therapy may hold a promising role in this context. ${ }^{94}$ To date, one clinical study has been planned to test gene therapy for inhibitor eradication in $\mathrm{HA}$; careful evaluation of preclinical studies in relevant animal models will be critical to support such trials.

4b) Inclusion of pediatric hemophilia patients. The 
pediatric patient population could also have tremendous benefit from gene therapy approaches. Routine factor prophylaxis generally requires indwelling central lines in infants and toddlers. The advent of emicizumab and other NFTs, which are being developed to be administered subcutaneously, could thus alleviate the burden in the care of hemophilia. Moreover, EHL FIX products are highly effective in HB patients with reduced frequency of injections, ${ }^{124}$ but all of these therapies would still require life-long infusions. Understanding the durability of efficacy and risk of potential adverse events from the different rAAV vector serotypes will allow consideration of the inclusion of young patients in gene therapy trials.

4c) Inclusion of patients with NAbs to AAV capsid proteins. Overall, $20-40 \%$ of candidates for intravascular AAV gene therapy are not eligible due to the presence of NAbs to the vector capsid resulting from cross-reactivity after natural exposure to WT-AAV. ${ }^{125}$ To date, it has been challenging to compare the efficacy of a given serotype across distinct studies due to a lack of normalization of the assays as most are developed "in house." Potential modifiers of the rates/titers of NAbs could include (1) reporter gene, (2) assay technique whether neutralizing assays, non-neutralizing antibody assays (ELISA) or cellular assays, (3) presence or absence of empty vector capsids, (4) age of the patient 65,126 and longitudinal studies in the same population over time, ${ }^{63}$ (5) underlying disease, ${ }^{62,63,65,126}$ and (6) vector manufacturing. Some candidates may also test positive for more than one serotype at a time. Further, the amount of antigen (AAV capsid protein) delivered by a gene therapy vector is likely to be orders of magnitude higher than natural infection, and whether these immune responses are similar or not remains to be determined. Finally, although antibodies largely mediate inhibition of vector transduction to the AAV capsid, there is evidence that, despite plasma depletion of IgG, there may still be some inhibitory effect on the vector transduction.

Several attempts aimed at the identification of either naturally occurring or engineered AAV serotypes are in development. However, to date, no candidate serotype allows for vector administration without neutralizing effect or vector re-administration. ${ }^{127}$ The latter especially may be needed to rescue transgene expression from either (a) the loss of the transduced cells by liver toxicity or (b) dilution of the transgene expression levels when delivered to young children, as the non-integrating nature of AAV precludes effective transfer of the therapeutic genes to the liver daughter cells upon cell division. To date, there is no clear evidence that such a strategy is highly effective in both preclinical and clinical models. Early efforts, including transient immunosuppression ${ }^{128}$ or altering ratio of empty "decoy" capsids, ${ }^{40,127}$ have not been successful, but there are some promising strategies. The use of plasmapheresis, ${ }^{129}$ catheter-guided perfusion of the portal vein to flush out NAbs, ${ }^{130}$ and more recently the use of IgG degrading enzyme of Streptococcus pyogenes (IdeS) $^{131}$ or Streptococcus zooepidermicus (IdeZ) ${ }^{132}$ could reduce enough anti-AAV IgG to allow vector efficacy. However, most of these strategies have been tried in the presence of low-titer NAbs $(<1: 20)$; some require invasive procedures, and may have other sequelae such as opportunistic infections. ${ }^{133}$ A recent study, employing rapamycin nanoparticles in conjunction with the rAAV vector, allowed for induction of tolerance to that vector serotype in mice and non-human primates, which could permit readministration. ${ }^{134}$ Vector re-administration was also possible in a limited study of IdeS in NHP, but additional safety data regarding anti-IdeS antibody development and the need for readministration is needed. The current lack of sound safety data using any of these strategies in combination with gene therapy precludes firm conclusion on their utility to circumvent anti-AAV NAbs. Although there is some preclinical and clinical evidence that NAbs to AAV5 may not prevent transgene expression, ${ }^{61}$ this requires further study as delineated above. Table 3 outlines a hypothetical strategy for the expansion of hemophilia gene therapy moving forward, and the efficacy and safety outcomes that warrant close monitoring as access is expanded.

5) Price and reimbursement of gene therapy for hemophilia: challenges facing a "one and done" treatment for an orphan disease. Motivated by the emerging success of rAAV liver gene therapy for hemophilia, there is an ongoing debate regarding the cost and payment for clinical gene therapy. A recent study analyzed the cost-effectiveness of a given gene therapy approach compared to standard, uncomplicated prophylaxis in non-inhibitor patients..$^{135}$ The Markov Model used by Machin et al. assesses disease outcomes (bleeding, surgical intervention, hospitalization) and quality of life against cost in a hypothetical adult HA population on prophylaxis. In this model, the cost of gene therapy was based on the first approved AAV drug in the US, developed for inherited retinal degenerative disease (estimated cost of $\$ 850,000$ ). Interestingly, in hemophilia, the gene therapy strategy was considered more cost-effective than protein-based prophylaxis with a superior quality of life performance.

Both payers and the hemophilia community are exploring ways to distribute this cost either on a per annum basis (depending on durability) or with a capped annuity. However, constraints in the existing healthcare systems will need to be overcome to make this a reality. Further, the initial production and development costs are driving current pricing; the hope would be that as gene therapy matures in the clinics, these costs will decline. When this occurs, gene therapy could become 
Table 3. Hypothetical strategy general assessment of subjects in early/advanced phase clinical trials for hemophilia.

\begin{tabular}{|c|c|c|c|c|}
\hline \multicolumn{5}{|c|}{ Proposed staged evaluation of candidates for AAV liver gene therapy in hemophilia } \\
\hline & Current & Step 1 & Step 2 & Step 3 \\
\hline Age at enrollment (years) & $\geq 18$ & $13-18$ & $13-18$ & $\leq 13$ \\
\hline Disease severity & Severe & Severe/Moderate & Severe/Moderate & Severe/Moderate \\
\hline \multicolumn{5}{|l|}{ Inhibitors } \\
\hline FVIII & $\begin{array}{l}\text { No current or prior } \\
\text { history of inhibitor }\end{array}$ & $\begin{array}{l}\text { History of transient } \\
\text { low titer inhibitor }\end{array}$ & $\begin{array}{l}\text { History of high titer, } \\
\text { previous ITI or } \\
\text { presence }\end{array}$ & $\begin{array}{l}\text { History of high titer, } \\
\text { previous ITI or } \\
\text { presence of inhibitor }\end{array}$ \\
\hline FIX & $\begin{array}{l}\text { No current or prior } \\
\text { history of inhibitor }\end{array}$ & $\begin{array}{l}\text { No current or prior } \\
\text { history of inhibitor }\end{array}$ & $\begin{array}{l}\text { No current or prior } \\
\text { history of inhibitor }\end{array}$ & $\begin{array}{l}\text { No current or prior } \\
\text { history of inhibitor }\end{array}$ \\
\hline Prior factor exposure & $20-50$ exposure days & Limited & Limited & Limited \\
\hline Anti AV U titor & $<1.5$ & Non-AAV $5 \leq 1: 5$ & Non-AAV $5 \leq 1: 5$ & Non-AAV $5 \leq 1: 5$ \\
\hline AMU-AAV NAD UIER & $\leq 1.5$ & AAV5 $>1: 5$ & AAV5 $>1: 5$ & AAV5 $>1: 5$ \\
\hline \multicolumn{5}{|c|}{ Long term follow-up requirements } \\
\hline \multicolumn{5}{|l|}{ Efficacy Outcomes } \\
\hline Factor levels & $\mathrm{X}$ & $\mathrm{X}$ & $\mathrm{X}$ & $\mathrm{X}$ \\
\hline $\begin{array}{l}\mathrm{ABR} \text { and factor } \\
\text { consumption }\end{array}$ & $\mathrm{X}$ & $\mathrm{X}$ & $\mathrm{X}$ & $\mathrm{X}$ \\
\hline Pain/discomfort & $\mathrm{X}$ & $\mathrm{X}$ & $\mathrm{X}$ & $\mathrm{X}$ \\
\hline $\begin{array}{l}\text { Mental health and quality } \\
\text { of life }\end{array}$ & $\mathrm{X}$ & $\mathrm{X}$ & $\mathrm{X}$ & $\mathrm{X}$ \\
\hline \multicolumn{5}{|l|}{ Safety Outcomes } \\
\hline Inhibitor & $\mathrm{X}$ & $\mathrm{X}$ & $\mathrm{X}$ & $\mathrm{X}$ \\
\hline $\begin{array}{l}\text { Vector shedding } \\
\text { (semen)* }\end{array}$ & $\mathrm{X}$ & $\mathrm{X}$ & $\mathrm{X}$ & $\mathrm{N} / \mathrm{A}$ \\
\hline Liver Function tests & $\mathrm{X}$ & $\mathrm{X}$ & $\mathrm{X}$ & $\mathrm{X}$ \\
\hline Screening for cancer** & $\mathrm{X}$ & $\mathrm{X}$ & $\mathrm{X}$ & \\
\hline Thrombosis & & $\mathrm{X}$ & $\mathrm{X}$ & $\mathrm{X}$ \\
\hline
\end{tabular}

*Safety concern that will establish risk as early patients are eligible.

**Imaging and laboratory (alpha-fetal protein) evaluation. Minimal duration of 5 years post enrollment.

an affordable and reasonable therapy in developing nations as well. Gene therapy affords the enormous potential to alleviate the burden of disease and improve the quality of life for people both in developed and developing countries, but how gene therapy is priced will play a significant role in its global impact.

Conclusions. A copious body of preclinical and clinical work has brought hemophilia gene therapy to the brink of becoming a tangible reality for hemophilia. The phase I/II data show the ability to ameliorate the bleeding phenotype and improve quality of life significantly and have paved the way for phase III trials. Evaluating gene therapy in $\mathrm{PwH}$ with pre-existing inhibitors or in pediatric subjects will likely be the next frontier for rAAV. Together with NFTs, gene therapy-based strategies point to a coming transformation in the treatment of hemophilia.

These successes should not minimize the challenges facing the gene therapy research community, including balancing vector dose to limit the cellular immune response while maximizing therapeutic efficacy and understanding the long-term risks from rAAV treatment. Indeed, in most hemophilia trials, the risk of AAV capsid-triggered cellular immune response and/or hepatotoxicity is proportional to the vector dose. This dose-response toxicity should be taken into consideration when assessing the development and choice of a therapeutic approach for genetic diseases with a long life expectancy, such as hemophilia. On the other hand, the dissociation between elevated transaminases and cellular immune response to capsid in recent trials is puzzling and deserves further study. Understanding this finding will require cooperation between industry and academia as differences in vector production, content, serotypes, and/or as yet undisclosed modifications could help explain these discrepancies. Higher vector doses likely carry a higher chance of inadvertent long-term complications. For hemophilia, patients and providers need to consider not only the goal FVIII or FIX expression level but also the amount of vector required to achieve this goal.

In clinical studies in HA, the considerable variability in the FVIII levels following gene therapy and the loss of FVIII levels observed without detection of AAV capsid-triggered immune response is a unique finding with an undetermined mechanism, which might impact long-term efficacy. It appears, at least, that this is not 
true for all rAAV vectors as neither uniQure's rAAV5 nor the SJCRH rAAV8 HB trials that have demonstrated a loss of FIX activity over 4 and 8 years of follow-up, respectively. ${ }^{40,78}$ Transduction and turnover of nonhepatocytes likely do not contribute to this finding, given the use of a liver-specific promoter. Transient expression outside the liver at very early time points may take place, ${ }^{136}$ but this is unlikely to affect long-term persistence. The ability to re-administer vector might become necessary if durable responses are not seen in the current trials. While basic research progress is being made on this front as well, it is not presently a reality in clinical practice.

Further, the risks of integration with or without genotoxicity as well as germline transmission for novel serotypes require further study with long-term followup of subjects in the current trials to allow for safe and rational expansion of eligible patient populations,

\section{References:}

1. Manco-Johnson, M.J., Abshire, T.C., Shapiro, A.D., Riske, B., Hacker, M.R., Kilcoyne, R., Ingram, J.D., Manco-Johnson, M.L., Funk, S., Jacobson, L., Valentino, L.A., Hoots, W.K., Buchanan, G.R., Dimichele, D., Recht, M., Brown, D., Leissinger, C., Bleak, S., Cohen, A., Mathew, P., Matsunaga, A., Medeiros, D., Nugent, D., Thomas, G.A., Thompson, A.A., Mcredmond, K., Soucie, J.M., Austin, H., and Evatt, B.L. Prophylaxis versus episodic treatment to prevent joint disease in boys with severe hemophilia. N Engl J Med, 2007. 357(6): p. 535-544. https://doi.org/10.1056/NEJMoa067659 PMid:17687129

2. Arruda, V., Doshi, B., and Samelson-Jones, B., Novel approaches to hemophilia therapy: successes and challenges. Blood, 2017. 130(21): p. 2251-2256

https://doi.org/10.1182/blood-2017-08-742312 PMid:29018078 PMCid:PMC5813735

3. Arruda, V.R., Doshi, B.S., and Samelson-Jones, B.J., Emerging therapies for hemophilia: controversies and unanswered questions. F1000Res, 2018 7.

https://doi.org/10.12688/f1000research.12491.1 PMid:29770199 PMCid:PMC5931262

4. Pipe, S.W., Montgomery, R.R., Pratt, K.P., Lenting, P.J., and Lillicrap, D., Life in the shadow of a dominant partner: the FVIII-VWF association and its clinical implications for hemophilia A. Blood, 2016. 128(16): p 2007-2016.

https://doi.org/10.1182/blood-2016-04-713289

PMid:27587878 PMCid:PMC5073181

5. Mahlangu, J., Oldenburg, J., Paz-Priel, I., Negrier, C., Niggli, M., Mancuso, M.E., Schmitt, C., Jiménez-Yuste, V., Kempton, C., Dhalluin, C., Callaghan, M.U., Bujan, W., Shima, M., Adamkewicz, J.I., Asikanius, E., Levy, G.G., and Kruse-Jarres, R., Emicizumab prophylaxis in patients who have hemophilia A without inhibitors. New England Journal of Medicine, 2018. 379(9): p. 811-822.

https://doi.org/10.1056/NEJMoa1803550

PMid:30157389

6. Oldenburg, J., Mahlangu, J.N., Kim, B., Schmitt, C., Callaghan, M.U., Young, G., Santagostino, E., Kruse-Jarres, R., Negrier, C., Kessler, C., Valente, N., Asikanius, E., Levy, G.G., Windyga, J., and Shima, M., Emicizumab prophylaxis in hemophilia A with inhibitors. New England Journal of Medicine, 2017. 377(9): p. 809-818. https://doi.org/10.1056/NEJMoa1703068 PMid:28691557

7. Sehgal, A., Barros, S., Ivanciu, L., Cooley, B., Qin, J., Racie, T., Hettinger, J., Carioto, M., Jiang, Y., Brodsky, J., Prabhala, H., Zhang, X., Attarwala, H., Hutabarat, R., Foster, D., Milstein, S., Charisse, K., Kuchimanchi, S., Maier, M.A., Nechev, L., Kandasamy, P., Kel'in, A.V., Nair, J.K., Rajeev, K.G., Manoharan, M., Meyers, R., Sorensen, B., Simon, A.R., Dargaud, Y., Negrier, C., Camire, R.M., and Akinc, A., An RNAi therapeutic targeting antithrombin to rebalance the coagulation system and promote hemostasis in hemophilia. Nat Med, 2015. 21(5): p. 492-497. specifically pediatric patients. Finally, development for $\mathrm{PwH}$ residing in developing nations should be considered to improve the global burden of hemophilia. Despite several advances in therapeutics for hemophilia, there has not been a significant decrease in the cost of care, which places an undue disease burden on $\mathrm{PwH}$ in lower socioeconomic strata. Making hemophilia gene therapy accessible and affordable for all will require advocacy and innovative solutions from the entire community. As the field moves forward and the above questions are answered, gene therapy could undoubtedly be a welcomed therapeutic revolution and provide health equity in hemophilia as proposed by Skinner et al. ${ }^{137}$

Acknowledgments. This work was supported by grants from National Heart, Lung, and Blood Institute grants U54- HL142012 (VRA) and RO1-HL137335-01 (VRA).

\section{https://doi.org/10.1038/nm.3847} PMid:25849132

8. Chowdary, P., Lethagen, S., Friedrich, U., Brand, B., Hay, C., Karim, F.A., Klamroth, R., Knoebl, P., Laffan, M., Mahlangu, J., Miesbach, W., Nielsen, J.D., Martin-Salces, M., Angchaisuksiri, P., and The Explorer, I., Safety and pharmacokinetics of anti-TFPI antibody (concizumab) in healthy volunteers and patients with hemophilia: a randomized first human dose trial. J Thromb Haemost, 2015.

https://doi.org/10.1111/jth.12864 PMid:25641556

9. Hamedani, N.S., Ruhl, H., Zimmermann, J.J., Heiseler, T., Oldenburg, J., Mayer, G., Potzsch, B., and Muller, J., In Vitro Evaluation of AptamerBased Reversible Inhibition of Anticoagulant Activated Protein $\mathrm{C}$ as a Novel Supportive Hemostatic Approach. Nucleic Acid Ther, 2016. 26(6): p. 355-362.

https://doi.org/10.1089/nat.2016.0645 PMid:27736370

10. Polderdijk, S.G.I., Baglin, T.P., and Huntington, J.A., Targeting activated protein $\mathrm{C}$ to treat hemophilia. Curr Opin Hematol, 2017. 24(5): p. 446452.

https://doi.org/10.1097/MOH.0000000000000364 PMid:28632502 PMCid:PMC5548501

11. Makris, M., Iorio, A., and Lenting, P.J., Emicizumab and thrombosis: The story so far. J Thromb Haemost, 2019. 17(8): p. 1269-1272. https://doi.org/10.1111/jth.14556 PMid:31368220

12. Novo Nordisk pauses the clinical trials investigating concizumab (antiTFPI mAB) in haemophilia A and B with or without inhibitors. 2020, Novo Nordisk: Bagsværd, Denmark.

13. Hough, C. and Lillicrap, D., Gene therapy for hemophilia: an imperative to succeed. J Thromb Haemost, 2005. 3(6): p. 1195-1205. https://doi.org/10.1111/i.1538-7836.2005.01401.x PMid:15946210

14. Hacein-Bey-Abina, S., Von Kalle, C., Schmidt, M., Le Deist, F., Wulffraat, N., Mcintyre, E., Radford, I., Villeval, J.L., Fraser, C.C., Cavazzana-Calvo, M., and Fischer, A., A serious adverse event after successful gene therapy for X-linked severe combined immunodeficiency. N Engl J Med, 2003. 348(3): p. 255-256. https://doi.org/10.1056/NEJM200301163480314 PMid:12529469

15. Arruda, V.R., Stedman, H.H., Haurigot, V., Buchlis, G., Baila, S., Favaro, P., Chen, Y., Franck, H.G., Zhou, S., Wright, J.F., Couto, L.B., Jiang, H., Pierce, G.F., Bellinger, D.A., Mingozzi, F., Nichols, T.C., and High, K.A., Peripheral transvenular delivery of adeno-associated viral vectors to skeletal muscle as a novel therapy for hemophilia B. Blood, 2010. 115(23): p. 4678-4688.

https://doi.org/10.1182/blood-2009-12-261156

PMid:20335222 PMCid:PMC2890180 
16. Haurigot, V., Mingozzi, F., Buchlis, G., Hui, D.J., Chen, Y., BasnerTschakarjan, E., Arruda, V.R., Radu, A., Franck, H.G., Wright, J.F., Zhou, S., Stedman, H.H., Bellinger, D.A., Nichols, T.C., and High, K.A., Safety of AAV factor IX peripheral transvenular gene delivery to muscle in hemophilia B dogs. Mol Ther, 2010. 18(7): p. 1318-1329. https://doi.org/10.1038/mt.2010.73 PMid:20424599 PMCid:PMC2911254

17. Du, L.M., Nurden, P., Nurden, A.T., Nichols, T.C., Bellinger, D.A. Jensen, E.S., Haberichter, S.L., Merricks, E., Raymer, R.A., Fang, J., Koukouritaki, S.B., Jacobi, P.M., Hawkins, T.B., Cornetta, K., Shi, Q., and Wilcox, D.A., Platelet-targeted gene therapy with human factor VIII establishes haemostasis in dogs with haemophilia A. Nat Commun, 2013. 4: p. 2773.

https://doi.org/10.1038/ncomms3773

PMid:24253479 PMCid:PMC3868233

18. Mezzina, M. and Merten, O.W., Adeno-associated viruses. Methods Mol Biol, 2011. 737: p. 211-234.

https://doi.org/10.1007/978-1-61779-095-9_9 PMid:21590399

19. Huser, D., Gogol-Doring, A., Chen, W., and Heilbronn, R., Adenoassociated virus type 2 wildtype and vector-mediated genomic integration profiles of human diploid fibroblasts analyzed by third-generation PacBio DNA sequencing. J Virol, 2014. 88(19): p. 11253-11263. https://doi.org/10.1128/JVI.01356-14

PMid:25031342 PMCid:PMC4178796

20. Samulski, R.J., Zhu, X., Xiao, X., Brook, J.D., Housman, D.E., Epstein, N., and Hunter, L.A., Targeted integration of adeno-associated virus (AAV) into human chromosome 19. EMBO J, 1991. 10(12): p. 3941-3950. https://doi.org/10.1002/j.1460-2075.1991.tb04964.x

PMid:1657596 PMCid:PMC453134

21. Schnepp, B.C., Chulay, J.D., Ye, G.J., Flotte, T.R., Trapnell, B.C., and Johnson, P.R., Recombinant Adeno-Associated Virus Vector Genomes Take the Form of Long-Lived, Transcriptionally Competent Episomes in Human Muscle. Hum Gene Ther, 2016. 27(1): p. 32-42.

https://doi.org/10.1089/hum.2015.136 PMid:26650966 PMCid:PMC5374867

22. Schnepp, B.C., Clark, K.R., Klemanski, D.L., Pacak, C.A., and Johnson, P.R., Genetic fate of recombinant adeno-associated virus vector genomes in muscle. J Virol, 2003. 77(6): p. 3495-3504. https://doi.org/10.1128/JVI.77.6.3495-3504.2003 PMid:12610125 PMCid:PMC149530

23. Song, S., Lu, Y., Choi, Y.K., Han, Y., Tang, Q., Zhao, G., Berns, K.I., and Flotte, T.R., DNA-dependent PK inhibits adeno-associated virus DNA integration. Proc Natl Acad Sci U S A, 2004. 101(7): p. 2112-2116. https://doi.org/10.1073/pnas.0307833100 PMid:14766968 PMCid:PMC357060

24. Berns, K.I., The Unusual Properties of the AAV Inverted Terminal Repeat. Hum Gene Ther, 2020. 31(9-10): p. 518-523. https://doi.org/10.1089/hum.2020.017 PMid:32079423

25. Smith, J.M., Grieger, J.C., and Samulski, R.J., Overcoming Bottlenecks in AAV Manufacturing for Gene Therapy.

26. Grieger, J.C., Soltys, S.M., and Samulski, R.J., Production of Recombinant Adeno-associated Virus Vectors Using Suspension HEK293 Cells and Continuous Harvest of Vector From the Culture Media for GMP FIX and FLT1 Clinical Vector. Mol Ther, 2016. 24(2): p. 287 297.

https://doi.org/10.1038/mt.2015.187 PMid:26437810 PMCid:PMC4817810

27. Matsushita, T., Elliger, S., Elliger, C., Podsakoff, G., Villarreal, L., Kurtzman, G.J., Iwaki, Y., and Colosi, P., Adeno-associated virus vectors can be efficiently produced without helper virus. Gene Ther, 1998. 5(7): p. $938-945$. https://doi.org/10.1038/sj.gt.3300680 PMid:9813665

28. Kotin, R.M., Large-scale recombinant adeno-associated virus production Hum Mol Genet, 2011. 20(R1): p. R2-6. https://doi.org/10.1093/hmg/ddr141 PMid:21531790 PMCid:PMC3095058

29. i, C. and Samulski, R.J., Engineering adeno-associated virus vectors for gene therapy. Nat Rev Genet, 2020. 21(4): p. 255-272. https://doi.org/10.1038/s41576-019-0205-4 PMid:32042148

30. Robert, M.A., Chahal, P.S., Audy, A., Kamen, A., Gilbert, R., and Gaillet, B., Manufacturing of recombinant adeno-associated viruses using mammalian expression platforms. Biotechnol J, 2017. 12(3). https://doi.org/10.1002/biot.201600193 PMid:28177193
31. Xu, L., Gao, C., Sands, M.S., Cai, S.R., Nichols, T.C., Bellinger, D.A., Raymer, R.A., Mccorquodale, S., and Ponder, K.P., Neonatal or hepatocyte growth factor-potentiated adult gene therapy with a retroviral vector results in therapeutic levels of canine factor IX for hemophilia B. Blood, 2003. 101(10): p. 3924-3932. https://doi.org/10.1182/blood-2002-10-3050 PMid:12531787

32. Miao, C.H., Ohashi, K., Patijn, G.A., Meuse, L., Ye, X., Thompson, A.R., and Kay, M.A., Inclusion of the hepatic locus control region, an intron, and untranslated region increases and stabilizes hepatic factor IX gene expression in vivo but not in vitro. Mol Ther, 2000. 1(6): p. 522-532. https://doi.org/10.1006/mthe.2000.0075 PMid:10933977

33. Choo, K.H., Gould, K.G., Rees, D.J., and Brownlee, G.G., Molecular cloning of the gene for human anti-haemophilic factor IX. Nature, 1982. 299(5879): p. 178-180.

https://doi.org/10.1038/299178a0 PMid:6287289

34. Buchlis, G., Podsakoff, G.M., Radu, A., Hawk, S.M., Flake, A.W., Mingozzi, F., and High, K.A., Factor IX expression in skeletal muscle of a severe hemophilia B patient 10 years after AAV-mediated gene transfer. Blood, 2012. 119(13): p. 3038-3041. https://doi.org/10.1182/blood-2011-09-382317 PMid:22271447 PMCid:PMC3321866

35. Manno, C.S., Chew, A.J., Hutchison, S., Larson, P.J., Herzog, R.W., Arruda, V.R., Tai, S.J., Ragni, M.V., Thompson, A., Ozelo, M., Couto, L.B., Leonard, D.G., Johnson, F.A., Mcclelland, A., Scallan, C., Skarsgard, E., Flake, A.W., Kay, M.A., High, K.A., and Glader, B., AAVmediated factor IX gene transfer to skeletal muscle in patients with severe hemophilia B. Blood, 2003. 101(8): p. 2963-2972. https://doi.org/10.1182/blood-2002-10-3296 PMid:12515715

36. Manno, C.S., Pierce, G.F., Arruda, V.R., Glader, B., Ragni, M., Rasko, J.J., Ozelo, M.C., Hoots, K., Blatt, P., Konkle, B., Dake, M., Kaye, R., Razavi, M., Zajko, A., Zehnder, J., Rustagi, P.K., Nakai, H., Chew, A., Leonard, D., Wright, J.F., Lessard, R.R., Sommer, J.M., Tigges, M., Sabatino, D., Luk, A., Jiang, H., Mingozzi, F., Couto, L., Ertl, H.C., High, K.A., and Kay, M.A., Successful transduction of liver in hemophilia by AAV-Factor IX and limitations imposed by the host immune response. Nat Med, 2006. 12(3): p. 342-347. https://doi.org/10.1038/nm1358 PMid:16474400

37. Mingozzi, F., Maus, M.V., Hui, D.J., Sabatino, D.E., Murphy, S.L., Rasko, J.E., Ragni, M.V., Manno, C.S., Sommer, J., Jiang, H., Pierce, G.F., Ertl, H.C., and High, K.A., CD8(+) T-cell responses to adeno-associated virus capsid in humans. Nat Med, 2007. 13(4): p. 419-422.

https://doi.org/10.1038/nm1549 PMid:17369837

38. Nathwani, A.C., Reiss, U.M., Tuddenham, E.G., Rosales, C., Chowdary, P., Mcintosh, J., Della Peruta, M., Lheriteau, E., Patel, N., Raj, D., Riddell, A., Pie, J., Rangarajan, S., Bevan, D., Recht, M., Shen, Y.M., Halka, K.G., Basner-Tschakarjan, E., Mingozzi, F., High, K.A., Allay, J., Kay, M.A., Ng, C.Y., Zhou, J., Cancio, M., Morton, C.L., Gray, J.T., Srivastava, D., Nienhuis, A.W., and Davidoff, A.M., Long-term safety and efficacy of factor IX gene therapy in hemophilia B. N Engl J Med, 2014. 371(21): p. 1994-2004.

https://doi.org/10.1056/NEJMoa1407309 PMid:25409372 PMCid:PMC4278802

39. Nathwani, A.C., Tuddenham, E.G., Rangarajan, S., Rosales, C., Mcintosh, J., Linch, D.C., Chowdary, P., Riddell, A., Pie, A.J., Harrington, C., O'beirne, J., Smith, K., Pasi, J., Glader, B., Rustagi, P., Ng, C.Y., Kay, M.A., Zhou, J., Spence, Y., Morton, C.L., Allay, J., Coleman, J., Sleep, S., Cunningham, J.M., Srivastava, D., Basner-Tschakarjan, E., Mingozzi, F., High, K.A., Gray, J.T., Reiss, U.M., Nienhuis, A.W., and Davidoff, A.M., Adenovirus-associated virus vector-mediated gene transfer in hemophilia B. N Engl J Med, 2011. 365(25): p. 2357-2365. https://doi.org/10.1056/NEJMoa1108046 PMid:22149959 PMCid:PMC3265081

40. Nathwani, A.C., Reiss, U., Tuddenham, E., Chowdary, P., Mcintosh, J., Riddell, A., Pie, J., Mahlangu, J.N., Recht, M., and Shen, Y.-M., AdenoAssociated Mediated Gene Transfer for Hemophilia B: 8 Year Follow up and Impact of Removing" Empty Viral Particles" on Safety and Efficacy of Gene Transfer. 2018, Am Soc Hematology. https://doi.org/10.1182/blood-2018-99-118334

41. Moriles, K.E. and Azer, S.A., Alanine Amino Transferase (ALT), in StatPearls. 2020: Treasure Island (FL).

42. George, L.A., Sullivan, S.K., Giermasz, A., Rasko, J.E.J., SamelsonJones, B.J., Ducore, J., Cuker, A., Sullivan, L.M., Majumdar, S., Teitel, 
J., Mcguinn, C.E., Ragni, M.V., Luk, A.Y., Hui, D., Wright, J.F., Chen, Y., Liu, Y., Wachtel, K., Winters, A., Tiefenbacher, S., Arruda, V.R., Van Der Loo, J.C.M., Zelenaia, O., Takefman, D., Carr, M.E., Couto, L.B. Anguela, X.M., and High, K.A., Hemophilia B Gene Therapy with a High-Specific-Activity Factor IX Variant. N Engl J Med, 2017. 377(23): p. $2215-2227$

https://doi.org/10.1056/NEJMoa1708538

PMid:29211678 PMCid:PMC6029626

43. Simioni, P., Tormene, D., Tognin, G., Gavasso, S., Bulato, C., Iacobelli, N.P., Finn, J.D., Spiezia, L., Radu, C., and Arruda, V.R., X-linked thrombophilia with a mutant factor IX (factor IX Padua). N Engl J Med 2009. 361(17): p. 1671-1675.

https://doi.org/10.1056/NEJMoa0904377 PMid:19846852

44. Arruda, V. and Samelson-Jones, B., Factor IX Padua: From Biochemistry to Gene Therapy. Blood, 2016. 128(22): p. SCI-9. https://doi.org/10.1182/blood.V128.22.SCI-9.SCI-9

45. Crudele, J.M., Finn, J.D., Siner, J.I., Martin, N.B., Niemeyer, G.P., Zhou, S., Mingozzi, F., Lothrop, C.D., Jr., and Arruda, V.R., AAV liver expression of FIX-Padua prevents and eradicates FIX inhibitor withou increasing thrombogenicity in hemophilia B dogs and mice. Blood, 2015 125(10): p. $1553-1561$. https://doi.org/10.1182/blood-2014-07-588194 PMid:25568350 PMCid:PMC4351503

46. Finn, J.D., Nichols, T.C., Svoronos, N., Merricks, E.P., Bellenger, D.A., Zhou, S., Simioni, P., High, K.A., and Arruda, V.R., The efficacy and the risk of immunogenicity of FIX Padua (R338L) in hemophilia B dogs treated by AAV muscle gene therapy. Blood, 2012. 120(23): p. 4521-4523 https://doi.org/10.1182/blood-2012-06-440123

PMid:22919027 PMCid:PMC3512231

47. George, L.A., Sullivan, S.K., Rasko, J.E., Giermasz, A., Samelson-Jones, B.J., Ducore, J.M., Teitel, J.M., Mcguinn, C.E., Runowski, A.R., and Wright, F., Efficacy and safety in 15 hemophilia B patients treated with the AAV gene therapy vector Fidanacogene Elaparvovec and followed for at least 1 year. 2019, American Society of Hematology Washington, DC. https://doi.org/10.1182/blood-2019-124091

48. Monahan, P.E., Sun, J., Gui, T., Hu, G., Hannah, W.B., Wichlan, D.G., Wu, Z., Grieger, J.C., Li, C., Suwanmanee, T., Stafford, D.W., Booth, C.J., Samulski, J.J., Kafri, T., Mcphee, S.W., and Samulski, R.J., Employing a gain-of-function factor IX variant R338L to advance the efficacy and safety of hemophilia B human gene therapy: preclinical evaluation supporting an ongoing adeno-associated virus clinical trial. Hum Gene Ther, 2015. 26(2): p. 69-81

https://doi.org/10.1089/hum.2014.106 PMid:25419787 PMCid:PMC4326268

49. Monahan, P.E., Walsh, C.E., Powell, J.S., Konkle, B., Josephson, N.C., Escobar, M.A., Mcphee, S.J., Litchev, B., Cecerle, M., Ewenstein, B.M. Rottensteiner, H., Rose, M.D.I., Reipert, B.M., Samulski, R.J., Orloff, J., and Scheiflinger, F., Update on phase 1/2 open-label trial of BAX335, an adeno-associated virus 8 (AAV8) vector-based gene therapy for program for phemophilia B. Journal of Thrombosis and Haemostasis, 2015. 13(Supplement 2): p. 87.

50. Chapin, J., Rottensteiner, H., Scheiflinger, F., and Monahan, P., An analysis of bleeding rates and factor IX consumption in the phase I/II BAX 335 gene therapy trial in subjects with hemophilia B. Res Pract Thromb Haemost, 2017. 1(Suppl. 1): p. 144

51. Pierce, G. and Iorio, A., Past, present and future of haemophilia gene therapy: From vectors and transgenes to known and unknown outcomes. Haemophilia, 2018. 24: p. 60-67. https://doi.org/10.1111/hae.13489 PMid:29878660

52. Wright, J.F., Codon Modification and PAMPs in Clinical AAV Vectors: The Tortoise or the Hare? Mol Ther, 2020. 28(3): p. 701-703. https://doi.org/10.1016/j.ymthe.2020.01.026 PMid:32035026

53. Chowdary, P., Shapiro, S., Davidoff, A.M., Reiss, U., Alade, R., Brooks, G., Dane, A., Mcintosh, J., Short, G., and Tuddenham, E., A single intravenous infusion of FLT180a results in factor IX activity levels of more than $40 \%$ and has the potential to provide a functional cure for patients with haemophilia B. Blood, 2018. 132(Supplement 1): p. 631631. https://doi.org/10.1182/blood-2018-99-118050

54. Chowdary P, S.S., Makris M, Evans G, Boyce S, Talks K, Dolan G, Reiss U, Phillips M, Riddell a, Peralta Mr, Quaye M, Tuddenham E, Krop J, Short G, Kar S, Smith a, Nathwani A. , A Novel Adeno Associated Virus (AAV) Gene Therapy (FLT180a) Achieves Normal FIX Activity Levels in Severe Hemophilia B (HB) Patients (B-AMAZE Study). Res Pract Thromb Haemost., 2020. 4
55. Carvalho, J., \#ISTH2020 - FLT180a Gene Therapy Shows Promise for Hemophilia B Patients in Phase 1/2 Trial, in Hemophilia News Today. 2020: Pensacola, FL.

56. Isth, A Novel Adeno Associated Virus (AAV) Gene Therapy (FLT180a) Achieves Normal FIX Activity Levels in Severe Hemophilia B (HB) Patients (B-AMAZE Study), in ISTH Congress Daily News. 2020.

57. Miesbach, W., Meijer, K., Coppens, M., Kampmann, P., Klamroth, R., Schutgens, R., Tangelder, M., Castaman, G., Schwable, J., Bonig, H., Seifried, E., Cattaneo, F., Meyer, C., and Leebeek, F.W.G., Gene therapy with adeno-associated virus vector 5-human factor IX in adults with hemophilia B. Blood, 2017.

https://doi.org/10.1182/blood-2017-09-804419 PMid:29246900 PMCid:PMC5833265

58. Pipe, S., Giermasz, A., Castaman, G., Key, N.S., Lattimore, S.U., Leebeek, F., Miesbach, W., Recht, M., Gomez, E., and Long, A., One Year Data from a Phase 2b Trial of AMT-061 (AAV5-Padua hFIX variant), an Enhanced Vector for Gene Transfer in Adults with Severe or ModerateSevere Hemophilia B. 2019, American Society of Hematology Washington, DC

https://doi.org/10.1182/blood-2019-128765

59. Pipe, S.W., Giermasz, A., Castaman, G., Key, N., Lattimore, S.U., Leebeek, F.W., Miesbach, W., Recht, M., Long, A., Gut, R., and Von Drygalski, A., AMT-061 (AAV5-Padua hFIX variant) an enchanced vector for gene transfer in adults with severe or moderate-severe hemophilia B: follow-up up to 9 months in a phase $2 \mathrm{~b}$ trial, in 71 st Annual National Hemophilia Foundation Bleeding Disorders Conference. 2019: Anaheim, CA.

60. Boutin, S., Monteilhet, V., Veron, P., Leborgne, C., Benveniste, O., Montus, M.F., and Masurier, C., Prevalence of serum IgG and neutralizing factors against adeno-associated virus (AAV) types 1, 2, 5, 6, 8 , and 9 in the healthy population: implications for gene therapy using AAV vectors. Hum Gene Ther, 2010. 21(6): p. 704-712. https://doi.org/10.1089/hum.2009.182 PMid:20095819

61. Majowicz, A., Nijmeijer, B., Lampen, M.H., Spronck, L., De Haan, M., Petry, H., Van Deventer, S.J., Meyer, C., Tangelder, M., and Ferreira, V., Therapeutic hFIX Activity Achieved after Single AAV5-hFIX Treatment in Hemophilia B Patients and NHPs with Pre-existing Anti-AAV5 NABs. Mol Ther Methods Clin Dev, 2019. 14: p. 27-36.

https://doi.org/10.1016/j.omtm.2019.05.009 PMid:31276009 PMCid:PMC6586596

62. Harrington, E.A., Sloan, J.L., Manoli, I., Chandler, R.J., Schneider, M., Mcguire, P.J., Calcedo, R., Wilson, J.M., and Venditti, C.P., Neutralizing Antibodies Against Adeno-Associated Viral Capsids in Patients with mut Methylmalonic Acidemia. Hum Gene Ther, 2016. 27(5): p. 345-353. https://doi.org/10.1089/hum.2015.092 PMid:26790480 PMCid:PMC4841085

63. Li, C., Narkbunnam, N., Samulski, R.J., Asokan, A., Hu, G., Jacobson, L.J., Manco-Johnson, M.J., Monahan, P.E., and Joint Outcome Study, I. Neutralizing antibodies against adeno-associated virus examined prospectively in pediatric patients with hemophilia. Gene Ther, 2012. 19(3): p. 288-294 https://doi.org/10.1038/gt.2011.90 PMid:21697954

64. Calcedo, R., Vandenberghe, L.H., Gao, G., Lin, J., and Wilson, J.M., Worldwide epidemiology of neutralizing antibodies to adeno-associated viruses. J Infect Dis, 2009. 199(3): p. 381-390. https://doi.org/10.1086/595830 PMid:19133809

65. Halbert, C.L., Miller, A.D., Mcnamara, S., Emerson, J., Gibson, R.L., Ramsey, B., and Aitken, M.L., Prevalence of neutralizing antibodies against adeno-associated virus (AAV) types 2, 5, and 6 in cystic fibrosis and normal populations: Implications for gene therapy using AAV vectors. Hum Gene Ther, 2006. 17(4): p. 440-447.

https://doi.org/10.1089/hum.2006.17.440 PMid:16610931 PMCid:PMC4292890

66. D'avola, D., Lopez-Franco, E., Sangro, B., Paneda, A., Grossios, N., GilFarina, I., Benito, A., Twisk, J., Paz, M., Ruiz, J., Schmidt, M., Petry, H., Harper, P., De Salamanca, R.E., Fontanellas, A., Prieto, J., and GonzalezAseguinolaza, G., Phase I open label liver-directed gene therapy clinical trial for acute intermittent porphyria. J Hepatol, 2016. 65(4): p. 776-783. https://doi.org/10.1016/j.jhep.2016.05.012 PMid:27212246

67. Lind, P., Larsson, K., Spira, J., Sydow-Backman, M., Almstedt, A., Gray, E., and Sandberg, H., Novel forms of B-domain deleted recombinant factor VIII molecules. Construction and biochemical characterization. European Journal of Biochemistry, 1995. 232: p. 19-27. https://doi.org/10.1111/j.1432-1033.1995.tb20776.x 
PMid:7556150

68. Pasi, K.J., Rangarajan, S., Mitchell, N., Lester, W., Symington, E., Madan, B., Laffan, M., Russell, C.B., Li, M., Pierce, G.F., and Wong, W.Y., Multiyear Follow-up of AAV5-hFVIII-SQ Gene Therapy for Hemophilia A. N Engl J Med, 2020. 382(1): p. 29-40. https://doi.org/10.1056/NEJMoa1908490 PMid:31893514

69. Rangarajan, S., Walsh, L., Lester, W., Perry, D., Madan, B., Laffan, M. Yu, H., Vettermann, C., Pierce, G.F., Wong, W.Y., and Pasi, K.J., AAV5Factor VIII Gene Transfer in Severe Hemophilia A. N Engl J Med, 2017. 377(26): p. 2519-2530.

https://doi.org/10.1056/NEJMoa1708483 PMid:29224506

70. Biomarin, BioMarin Provides Additional Data from Recent 4 Year Update of Ongoing Phase 1/2 Study of Valoctocogene Roxaparvovec Gene Therapy for Severe Hemophilia A in Late-Breaking Ora Presentation at World Federation of Hemophilia Virtual Summit. 2020: San Rafael, CA.

71. Lisowski, L., Dane, A.P., Chu, K., Zhang, Y., Cunningham, S.C., Wilson, E.M., Nygaard, S., Grompe, M., Alexander, I.E., and Kay, M.A., Selection and evaluation of clinically relevant AAV variants in a xenograft liver model. Nature, 2014. 506(7488): p. 382-386. https://doi.org/10.1038/nature12875 PMid:24390344 PMCid:PMC3939040

72. High, K.A., George, L.A., Eyster, M.E., Sullivan, S.K., Ragni, M.V., Croteau, S.E., Samelson-Jones, B.J., Evans, M., Joseney-Antoine, M., and Macdougall, A., A phase $1 / 2$ trial of investigational SPK-8011 in hemophilia A demonstrates durable expression and prevention of bleeds. Blood, 2018. 132(Supplement 1): p. 487-487. https://doi.org/10.1182/blood-2018-99-115495

73. George L, Eyster E, Ragni M, Sullivan S, Samelson-Jones B, Evans M, Macdougall A, Curran M, Tompkins S, Wachtel K, Takefman D, Reape K, Mingozzi F, Monahan P, Anguela X, and K., H., Phase I/II Trial of SPK-8011: Stable and Durable FVIII Expression for $>2$ Years with Significant ABR Improvements in Initial Dose Cohorts Following AAVMediated FVIII Gene Transfer for Hemophilia A [abstract]. . Res Pract Thromb Haemost, 2020. 4.

74. Mcintosh, J., Lenting, P.J., Rosales, C., Lee, D., Rabbanian, S., Raj, D., Patel, N., Tuddenham, E.G., Christophe, O.D., Mcvey, J.H., Waddington, S., Nienhuis, A.W., Gray, J.T., Fagone, P., Mingozzi, F., Zhou, S.Z., High, K.A., Cancio, M., Ng, C.Y., Zhou, J., Morton, C.L., Davidoff, A.M., and Nathwani, A.C., Therapeutic levels of FVIII following a single peripheral vein administration of rAAV vector encoding a novel human factor VIII variant. Blood, 2013. 121(17): p. 3335-3344. https://doi.org/10.1182/blood-2012-10-462200 PMid:23426947 PMCid:PMC3637010

75. Nathwani, A.C., Tuddenham, E., Chowdary, P., Mcintosh, J., Lee, D. Rosales, C., Phillips, M., Pie, J., Junfang, Z., and Meagher, M.M., GO-8: preliminary results of a phase I/II dose escalation trial of gene therapy for haemophilia a using a novel human factor VIII variant. Blood, 2018. 132(Supplement 1): p. 489-489. https://doi.org/10.1182/blood-2018-99-118256

76. Mah, C., Sarkar, R., Zolotukhin, I., Schleissing, M., Xiao, X., Kazazian, H.H., and Byrne, B.J., Dual vectors expressing murine factor VIII result in sustained correction of hemophilia A mice. Hum Gene Ther, 2003. 14(2): p. 143-152.

https://doi.org/10.1089/104303403321070838 PMid:12614565

77. Sabatino, D.E., Lange, A.M., Altynova, E.S., Sarkar, R., Zhou, S. Merricks, E.P., Franck, H.G., Nichols, T.C., Arruda, V.R., and Kazazian, H.H., Jr., Efficacy and safety of long-term prophylaxis in severe hemophilia A dogs following liver gene therapy using AAV vectors. Mol Ther, 2011. 19(3): p. 442-449. https://doi.org/10.1038/mt.2010.240

\section{PMid:21081906 PMCid:PMC3048175}

78. Miesbach, W., Meijer, K., Coppens, M., Kampmann, P., Klamroth, D., Schutgens, R., Castaman, G., Seifried, E., Schwaeble, J., Bönig, H., Sawyer, E.K., and Leebeek, F.W.G., Stable FIX Expression and Durable Reductions in Bleeding and Factor IX Consumption for up to 4 Years Following AMT-060 Gene Therapy in Adults with Severe or ModerateSevere Hemophilia B. Blood, 2019. 134(Supplement_1): p. 2059-2059. https://doi.org/10.1182/blood-2019-122535

79. Den Uijl, I.E., Mauser Bunschoten, E.P., Roosendaal, G., Schutgens, R.E., Biesma, D.H., Grobbee, D.E., and Fischer, K., Clinical severity of haemophilia A: does the classification of the $1950 \mathrm{~s}$ still stand? Haemophilia, 2011. 17(6): p. 849-853.

https://doi.org/10.1111/j.1365-2516.2011.02539.x PMid:21545376
80. Soucie, J.M., Monahan, P.E., Kulkarni, R., Konkle, B.A., Mazepa, M.A., and Network, U.S.H.T.C., The frequency of joint hemorrhages and procedures in nonsevere hemophilia A vs B. Blood Adv, 2018. 2(16): p. 2136-2144.

https://doi.org/10.1182/bloodadvances.2018020552 PMid:30143528 PMCid:PMC6113607

81. Koster, T., Blann, A.D., Briet, E., Vandenbroucke, J.P., and Rosendaal, F.R., Role of clotting factor VIII in effect of von Willebrand factor on occurrence of deep-vein thrombosis. Lancet, 1995. 345(8943): p. 152-155. https://doi.org/10.1016/S0140-6736(95)90166-3

82. Rosendaal, F.R., High levels of factor VIII and venous thrombosis. Thromb Haemost, 2000. 83(1): p. 1-2. https://doi.org/10.1055/s-0037-1613745 PMid:10669143

83. Kyrle, P.A., Minar, E., Hirschl, M., Bialonczyk, C., Stain, M., Schneider, B., Weltermann, A., Speiser, W., Lechner, K., and Eichinger, S., High plasma levels of factor VIII and the risk of recurrent venous thromboembolism. N Engl J Med, 2000. 343(7): p. 457-462.

https://doi.org/10.1056/NEJM200008173430702

PMid:10950667

84. Van Hylckama Vlieg, A., Van Der Linden, I.K., Bertina, R.M., and Rosendaal, F.R., High levels of factor IX increase the risk of venous thrombosis. Blood, 2000. 95(12): p. 3678-3682. https://doi.org/10.1182/blood.V95.12.3678 PMid:10845896

85. Nossent, A.Y., Eikenboom, J.C., and Bertina, R.M., Plasma coagulation factor levels in venous thrombosis. Semin Hematol, 2007. 44(2): p. 77-84. https://doi.org/10.1053/j.seminhematol.2007.01.006 PMid:17433899

86. Iorio, A., Skinner, M.W., Clearfield, E., Messner, D., Pierce, G.F., Witkop, M., Tunis, S., and Core, H.E.M.P., Core outcome set for gene therapy in haemophilia: Results of the coreHEM multistakeholder project. Haemophilia, 2018. 24(4): p. e167-e172. https://doi.org/10.1111/hae.13504 PMid:29781145

87. Nogami, K. and Shima, M., Phenotypic heterogeneity of hemostasis in severe hemophilia. Semin Thromb Hemost, 2015. 41(8): p. 826-831. https://doi.org/10.1055/s-0034-1395349 PMid:25615433

88. Pavlova, A. and Oldenburg, J., Defining severity of hemophilia: more than factor levels. Semin Thromb Hemost, 2013. 39(7): p. 702-710. https://doi.org/10.1055/s-0033-1354426 PMid:24026911

89. Doshi, B.S. and Arruda, V.R., Gene therapy for hemophilia: what does the future hold? Ther Adv Hematol, 2018. 9(9): p. 273-293. https://doi.org/10.1177/2040620718791933 PMid:30210756 PMCid:PMC6130099

90. Nguyen, G.N., Everett, J.K., Raymond, H., Kafle, S., Merricks, E.P., Kazazian, H.H., Nichols, T.C., Bushman, F.D., and Sabatino, D.E., LongTerm AAV-Mediated Factor VIII Expression in Nine Hemophilia A Dogs: A 10 Year Follow-up Analysis on Durability, Safety and Vector Integration. 2019, American Society of Hematology Washington, DC. https://doi.org/10.1182/blood-2019-126007

91. Nakai, H., Herzog, R.W., Hagstrom, J.N., Walter, J., Kung, S.H., Yang, E.Y., Tai, S.J., Iwaki, Y., Kurtzman, G.J., Fisher, K.J., Colosi, P., Couto, L.B., and High, K.A., Adeno-associated viral vector-mediated gene transfer of human blood coagulation factor IX into mouse liver. Blood, 1998. 91(12): p. 4600-4607.

https://doi.org/10.1182/blood.V91.12.4600

PMid:9616156

92. Kay, M.A., Rothenberg, S., Landen, C.N., Bellinger, D.A., Leland, F., Toman, C., Finegold, M., Thompson, A.R., Read, M.S., Brinkhous, K.M., and Et Al., In vivo gene therapy of hemophilia B: sustained partial correction in factor IX-deficient dogs. Science, 1993. 262(5130): p. 117 119.

https://doi.org/10.1126/science.8211118 PMid:8211118

93. Finn, J.D., Ozelo, M.C., Sabatino, D.E., Franck, H.W., Merricks, E.P., Crudele, J.M., Zhou, S., Kazazian, H.H., Lillicrap, D., Nichols, T.C., and Arruda, V.R., Eradication of neutralizing antibodies to factor VIII in canine hemophilia A after liver gene therapy. Blood, 2010. 116(26): p. 5842-5848. https://doi.org/10.1182/blood-2010-06-288001 PMid:20876851 PMCid:PMC3031380

94. Samelson-Jones, B.J. and Arruda, V.R., Translational Potential of Immune Tolerance Induction by AAV Liver-Directed Factor VIII Gene Therapy for Hemophilia A. Front Immunol, 2020. 11: p. 618. https://doi.org/10.3389/fimmu.2020.00618 


\section{PMid:32425925 PMCid:PMC7212376}

95. Kazazian, H.H., Jr., An estimated frequency of endogenous insertional mutations in humans. Nat Genet, 1999. 22(2): p. 130. https://doi.org/10.1038/9638 PMid:10369250

96. Epstein, S., Bauer, S., Miller, A., Pilaro, A., and Noguchi, P., FDA comments on phase I clinical trials without vector biodistribution data Nat Genet, 1999. 22(4): p. 326. https://doi.org/10.1038/11895 PMid:10431234

97. Arruda, V.R., Fields, P.A., Milner, R., Wainwright, L., De Miguel, M.P., Donovan, P.J., Herzog, R.W., Nichols, T.C., Biegel, J.A., Razavi, M. Dake, M., Huff, D., Flake, A.W., Couto, L., Kay, M.A., and High, K.A., Lack of germline transmission of vector sequences following systemic administration of recombinant AAV-2 vector in males. Mol Ther, 2001. 4(6): p. 586-592.

https://doi.org/10.1006/mthe.2001.0491 PMid:11735343

98. Wellman, J., Mingozzi, F., Ozelo, M., Arruda, V., Podsakoff, G.M., Chen, Y., Konkle, B., Blatt, P., Hoots, K., Raffini, L., Rasko, J.E., Ragni, M., and High, K., Results from long-term follow-up of severe hemophilia B subjects previously enrolled in a clinical study of AAV2-FIX gene transfer to the liver. Molecular Therapy, 2012. 20: p. S28-S29. https://doi.org/10.1016/S1525-0016(16)35873-7

99. Boyce, N., Trial halted after gene shows up in semen. Nature, 2001. 414(6865): p. 677.

https://doi.org/10.1038/414677a PMid:11742355

100.Favaro, P., Downey, H.D., Zhou, J.S., Wright, J.F., Hauck, B., Mingozzi, F., High, K.A., and Arruda, V.R., Host and vector-dependent effects on the risk of germline transmission of AAV vectors. Mol Ther, 2009. 17(6): p. $1022-1030$ https://doi.org/10.1038/mt.2009.56 PMid:19293773 PMCid:PMC2835193

101.Schuettrumpf, J., Liu, J.H., Couto, L.B., Addya, K., Leonard, D.G., Zhen, Z., Sommer, J., and Arruda, V.R., Inadvertent germline transmission of AAV2 vector: findings in a rabbit model correlate with those in a human clinical trial. Mol Ther, 2006. 13(6): p. 1064-1073 https://doi.org/10.1016/j.ymthe.2006.03.002 PMid:16631412

102.Fda, Guidance for Industry: Gene Therapy Clinical Trials - Observing Subjects for Delayed Adverse Events, D.o.H.a.H. Services, Editor. 2006 Rockville, MD.

103.Buning, H. and Schmidt, M., Adeno-associated Vector Toxicity-To Be or Not to Be? Mol Ther, 2015. 23(11): p. 1673-1675. https://doi.org/10.1038/mt.2015.182 PMid:26606658 PMCid:PMC4817949

104.Srivastava, A. and Carter, B.J., AAV Infection: Protection from Cancer Hum Gene Ther, 2017. 28(4): p. 323-327. https://doi.org/10.1089/hum.2016.147 PMid:27832705 PMCid:PMC5399746

105.Donsante, A., Miller, D.G., Li, Y., Vogler, C., Brunt, E.M., Russell, D.W. and Sands, M.S., AAV vector integration sites in mouse hepatocellular carcinoma. Science, 2007. 317(5837): p. 477. https://doi.org/10.1126/science. 1142658 PMid:17656716

106.Donsante, A., Vogler, C., Muzyczka, N., Crawford, J.M., Barker, J., Flotte, T., Campbell-Thompson, M., Daly, T., and Sands, M.S., Observed incidence of tumorigenesis in long-term rodent studies of rAAV vectors. Gene Ther, 2001. 8(17): p. 1343-1346. https://doi.org/10.1038/sj.gt.3301541 PMid:11571571

107.Gauttier, V., Pichard, V., Aubert, D., Kaeppel, C., Schmidt, M., Ferry, N., and Conchon, S., No tumour-initiating risk associated with scAAV transduction in newborn rat liver. Gene Ther, 2013. 20(7): p. 779-784. https://doi.org/10.1038/gt.2013.7 PMid:23364314

108.Bell, P., Wang, L., Lebherz, C., Flieder, D.B., Bove, M.S., Wu, D., Gao, G.P., Wilson, J.M., and Wivel, N.A., No evidence for tumorigenesis of AAV vectors in a large-scale study in mice. Mol Ther, 2005. 12(2): p. 299-306.

https://doi.org/10.1016/j.ymthe.2005.03.020 PMid:16043099

109.Li, H., Malani, N., Hamilton, S.R., Schlachterman, A., Bussadori, G., Edmonson, S.E., Shah, R., Arruda, V.R., Mingozzi, F., Wright, J.F., Bushman, F.D., and High, K.A., Assessing the potential for AAV vector genotoxicity in a murine model. Blood, 2011. 117(12): p. 3311-3319. https://doi.org/10.1182/blood-2010-08-302729
PMid:21106988 PMCid:PMC3069673

110.Niemeyer, G.P., Herzog, R.W., Mount, J., Arruda, V.R., Tillson, D.M., Hathcock, J., Van Ginkel, F.W., High, K.A., and Lothrop, C.D., Jr., Longterm correction of inhibitor-prone hemophilia B dogs treated with liverdirected AAV2-mediated factor IX gene therapy. Blood, 2009. 113(4): p. $797-806$.

https://doi.org/10.1182/blood-2008-10-181479 PMid:18957684 PMCid:PMC2630266

111.Kaeppel, C., Beattie, S.G., Fronza, R., Van Logtenstein, R., Salmon, F., Schmidt, S., Wolf, S., Nowrouzi, A., Glimm, H., Von Kalle, C., Petry, H., Gaudet, D., and Schmidt, M., A largely random AAV integration profile after LPLD gene therapy. Nat Med, 2013. 19(7): p. 889-891. https://doi.org/10.1038/nm.3230 PMid:23770691

112.Gil-Farina, I., Fronza, R., Kaeppel, C., Lopez-Franco, E., Ferreira, V., D'avola, D., Benito, A., Prieto, J., Petry, H., Gonzalez-Aseguinolaza, G., and Schmidt, M., Recombinant AAV Integration Is Not Associated With Hepatic Genotoxicity in Nonhuman Primates and Patients. Mol Ther, 2016. 24(6): p. 1100-1105.

https://doi.org/10.1038/mt.2016.52 PMid:26948440 PMCid:PMC492332

113.Chandler, R.J., Lafave, M.C., Varshney, G.K., Trivedi, N.S., CarrilloCarrasco, N., Senac, J.S., Wu, W., Hoffmann, V., Elkahloun, A.G., Burgess, S.M., and Venditti, C.P., Vector design influences hepatic genotoxicity after adeno-associated virus gene therapy. J Clin Invest, 2015. 125(2): p. 870-880.

https://doi.org/10.1172/JCI79213

PMid:25607839 PMCid:PMC4319425

114.Nault, J.C., Datta, S., Imbeaud, S., Franconi, A., Mallet, M., Couchy, G., Letouze, E., Pilati, C., Verret, B., Blanc, J.F., Balabaud, C., Calderaro, J., Laurent, A., Letexier, M., Bioulac-Sage, P., Calvo, F., and Zucman-Rossi, J., Recurrent AAV2-related insertional mutagenesis in human hepatocellular carcinomas. Nat Genet, 2015. 47(10): p. 1187-1193. https://doi.org/10.1038/ng.3389

\section{PMid:26301494}

115.Berns, K.I., Byrne, B.J., Flotte, T.R., Gao, G., Hauswirth, W.W., Herzog, R.W., Muzyczka, N., Vandendriessche, T., Xiao, X., Zolotukhin, S., and Srivastava, A., Adeno-Associated Virus Type 2 and Hepatocellular Carcinoma? Hum Gene Ther, 2015. 26(12): p. 779-781.

https://doi.org/10.1089/hum.2015.29014.kib PMid:26690810 PMCid:PMC4809064

116.Berns, K.I. and Muzyczka, N., AAV: An Overview of Unanswered Questions. Hum Gene Ther, 2017. 28(4): p. 308-313.

https://doi.org/10.1089/hum.2017.048

PMid:28335618 PMCid:PMC5399733

117.Logan, G.J., Dane, A.P., Hallwirth, C.V., Smyth, C.M., Wilkie, E.E., Amaya, A.K., Zhu, E., Khandekar, N., Ginn, S.L., Liao, S.H.Y., Cunningham, S.C., Sasaki, N., Cabanes-Creus, M., Tam, P.P.L., Russell, D.W., Lisowski, L., and Alexander, I.E., Identification of liver-specific enhancer-promoter activity in the $3^{\prime}$ untranslated region of the wildtype AAV2 genome. Nat Genet, 2017. 49(8): p. 1267-1273.

https://doi.org/10.1038/ng.3893

PMid:28628105

118.George, L.A., Ragni, M.V., Samelson-Jones, B.J., Cuker, A., Runoski, A.R., Cole, G., Wright, F., Chen, Y., Hui, D.J., Wachtel, K., Takefman, D., Couto, L.B., Reape, K.Z., Carr, M.E., Anguela, X.M., and Katherine A. High, M., Spk-8011: Preliminary Results from a Phase 1/2 Dose Escalation Trial of an Investigational AAV-Mediated Gene Therapy for Hemophilia A. Blood, 2017. 130(Supp11): p. 604.

119.George, L.A., Ragni, M.V., Rasko, J.E.J., Raffini, L.J., Samelson-Jones, B.J., Ozelo, M., Hazbon, M., Runowski, A.R., Wellman, J.A., Wachtel, K., Chen, Y., Anguela, X.M., Kuranda, K., Mingozzi, F., and High, K.A., Long-Term Follow-Up of the First in Human Intravascular Delivery of AAV for Gene Transfer: AAV2-hFIX16 for Severe Hemophilia B. Mol Ther, 2020. https://doi.org/10.1016/j.ymthe.2020.06.001

120.Ema, Guideline on follow-up of patients administered with gene therapy medicinal products. 2009: London, UK. p. 1-12.

121.Mount, J.D., Herzog, R.W., Tillson, D.M., Goodman, S.A., Robinson, N., Mccleland, M.L., Bellinger, D., Nichols, T.C., Arruda, V.R., Lothrop, C.D., Jr., and High, K.A., Sustained phenotypic correction of hemophilia $\mathrm{B}$ dogs with a factor IX null mutation by liver-directed gene therapy. Blood, 2002. 99(8): p. 2670-2676. https://doi.org/10.1182/blood.V99.8.2670 PMid:11929752

122.Van Dijk, K., Van Der Bom, J.G., Bax, K.N., Van Der Zee, D.C., and Van Den Berg, M.H., Use of implantable venous access devices in children 
with severe hemophilia: benefits and burden. Haematologica, 2004. 89(2): p. 189-194.

123.Hay, C.R., Dimichele, D.M., and International Immune Tolerance, S., The principal results of the International Immune Tolerance Study: a randomized dose comparison. Blood, 2012. 119(6): p. 1335-1344. https://doi.org/10.1182/blood-2011-08-369132 PMid:22101900

124.Arruda, V.R., Doshi, B.S., and Samelson-Jones, B.J., Novel approaches to hemophilia therapy: successes and challenges. Blood, 2017. 130(21) p. $2251-2256$ https://doi.org/10.1182/blood-2017-08-742312 PMid:29018078 PMCid:PMC5813735

125.Stanford, S., Pink, R., Creagh, D., Clark, A., Lowe, G., Curry, N., Pasi, J., Perry, D., Fong, S., Hayes, G., Chandrakumaran, K., and Rangarajan, S., Adenovirus-associated antibodies in UK cohort of hemophilia patients: A seroprevalence study of the presence of adenovirus-associated virus vector-serotypes AAV5 and AAV8 neutralizing activity and antibodies in patients with hemophilia A. Res Pract Thromb Haemost, 2019. 3(2): p. 261-267.

https://doi.org/10.1002/rth2.12177 PMid:31011710 PMCid:PMC6462753

126.Aronson, S.J., Veron, P., Collaud, F., Hubert, A., Delahais, V., Honnet, G., De Knegt, R.J., Junge, N., Baumann, U., Di Giorgio, A., D'antiga, L., Ginocchio, V.M., Brunetti-Pierri, N., Labrune, P., Beuers, U., Bosma, P.J. and Mingozzi, F., Prevalence and Relevance of Pre-Existing Anti-AdenoAssociated Virus Immunity in the Context of Gene Therapy for CriglerNajjar Syndrome. Hum Gene Ther, 2019. 30(10): p. 1297-1305. https://doi.org/10.1089/hum.2019.143 PMid:31502485 PMCid:PMC6763963

127.Ertl, H.C.J. and High, K.A., Impact of AAV Capsid-Specific T-Cell Responses on Design and Outcome of Clinical Gene Transfer Trials with Recombinant Adeno-Associated Viral Vectors: An Evolving Controversy. Hum Gene Ther, 2017. 28(4): p. 328-337. https://doi.org/10.1089/hum.2016.172 PMid:28042943

128.Unzu, C., Hervas-Stubbs, S., Sampedro, A., Mauleon, I., Mancheno, U. Alfaro, C., De Salamanca, R.E., Benito, A., Beattie, S.G., Petry, H., Prieto, J., Melero, I., and Fontanellas, A., Transient and intensive pharmacological immunosuppression fails to improve AAV-based liver gene transfer in non-human primates. J Transl Med, 2012. 10: p. 122. https://doi.org/10.1186/1479-5876-10-122 PMid:22704060 PMCid:PMC3412719

129.Monteilhet, V., Saheb, S., Boutin, S., Leborgne, C., Veron, P., Montus, M.F., Moullier, P., Benveniste, O., and Masurier, C., A 10 patient case report on the impact of plasmapheresis upon neutralizing factors agains adeno-associated virus (AAV) types 1, 2, 6, and 8. Mol Ther, 2011 19(11): p. 2084-2091.

https://doi.org/10.1038/mt.2011.108
PMid:21629225 PMCid:PMC3222518

130.Mimuro, J., Mizukami, H., Hishikawa, S., Ikemoto, T., Ishiwata, A., Sakata, A., Ohmori, T., Madoiwa, S., Ono, F., Ozawa, K., and Sakata, Y., Minimizing the inhibitory effect of neutralizing antibody for efficient gene expression in the liver with adeno-associated virus 8 vectors. Mol Ther, 2013. 21(2): p. 318-323.

https://doi.org/10.1038/mt.2012.258

PMid:23247100 PMCid:PMC3594013

131.Leborgne, C., Barbon, E., Alexander, J.M., Hanby, H., Delignat, S., Cohen, D.M., Collaud, F., Muraleetharan, S., Lupo, D., Silverberg, J., Huang, K., Van Wittengerghe, L., Marolleau, B., Miranda, A., Fabiano, A., Daventure, V., Beck, H., Anguela, X.M., Ronzitti, G., Armour, S.M., Lacroix-Desmazes, S., and Mingozzi, F., IgG-cleaving endopeptidase enables in vivo gene therapy in the presence of anti-AAV neutralizing antibodies. Nat Med, 2020. 26(7): p. 1096-1101. https://doi.org/10.1038/s41591-020-0911-7 PMid:32483358

132.Elmore, Z.C., Oh, D.K., Simon, K.E., Fanous, M.M., and Asokan, A., Rescuing AAV gene transfer from antibody neutralization with an IgGdegrading enzyme. bioRxiv, 2020: p. 2020.2005.2012.092122. https://doi.org/10.1101/2020.05.12.092122

133.Jordan, S.C., Lorant, T., and Choi, J., IgG Endopeptidase in Highly Sensitized Patients Undergoing Transplantation. N Engl J Med, 2017. 377(17): p. 1693-1694. https://doi.org/10.1056/NEJMoa1612567

134.Meliani, A., Boisgerault, F., Hardet, R., Marmier, S., Collaud, F., Ronzitti, G., Leborgne, C., Costa Verdera, H., Simon Sola, M., Charles, S., Vignaud, A., Van Wittenberghe, L., Manni, G., Christophe, O., Fallarino, F., Roy, C., Michaud, A., Ilyinskii, P., Kishimoto, T.K., and Mingozzi, F., Antigen-selective modulation of AAV immunogenicity with tolerogenic rapamycin nanoparticles enables successful vector re-administration. Nat Commun, 2018. 9(1): p. 4098. https://doi.org/10.1038/s41467-018-06621-3 PMid:30291246 PMCid:PMC6173722

135.Machin, N., Ragni, M.V., and Smith, K.J., Gene therapy in hemophilia A: a cost-effectiveness analysis. Blood Adv, 2018. 2(14): p. 1792-1798. https://doi.org/10.1182/bloodadvances.2018021345 PMid:30042145 PMCid:PMC6058236

136.Lang, J.F., Toulmin, S.A., Brida, K.L., Eisenlohr, L.C., and Davidson, B.L., Standard screening methods underreport AAV-mediated transduction and gene editing. Nat Commun, 2019. 10(1): p. 3415. https://doi.org/10.1038/s41467-019-11321-7 PMid:31363095 PMCid:PMC6667494

137.Skinner, M.W., Nugent, D., Wilton, P., O'mahony, B., Dolan, G., O'hara, J., and Berntorp, E., Achieving the unimaginable: Health equity in haemophilia. Haemophilia, 2020. 26(1): p. 17-24.

https://doi.org/10.1111/hae.13862 PMid:31724316 